\title{
Total organic carbon distribution and budget through the Strait of Gibraltar in April 1998
}

\author{
Evgeny V. Dafner ${ }^{\mathrm{a}, *}$, Richard Sempéré ${ }^{\mathrm{a}}$, Harry L. Bryden ${ }^{\mathrm{b}}$ \\ a Microbiologie Marine (CNRS / INSU, EP2032), Université de la Mediterranée-Campus de Luminy, Case 907, Marseille Cedex 9, France \\ ${ }^{\mathrm{b}}$ Southampton Oceanography Centre, Empress Dock, Southampton SO14 3ZH, UK
}

Received 6 December 1999; received in revised form 16 October 2000; accepted 18 October 2000

\begin{abstract}
In order to investigate total organic carbon (TOC) exchange through the Strait of Gibraltar, samples were taken along two sections from the western (Gulf of Cádiz) and eastern (Western Alboran Sea) entrances of the Strait and at the middle of the Strait in April 1998. TOC was measured by using a high-temperature catalytic oxidation method. The results referenced here are based on a three-layer model of water mass exchange through the Strait, which includes the Atlantic inflow, Mediterranean outflow and an interface layer in between. All layers were characterised by a decrease of TOC concentrations from the Gulf of Cádiz to the Western Alboran Sea: from 60-79 to 59-66 $\mu \mathrm{M} \mathrm{C}$ in the Atlantic inflow and from 40-60 to $38-52 \mu \mathrm{M} \mathrm{C}$ in the Mediterranean waters, respectively. TOC concentrations in the modified North Atlantic Central Water
\end{abstract}

Strait. Our results indicate that the short-term variability caused by the tide greatly impacts the TOC distribution, particularly in the Gulf of Cádiz. The TOC input from the Atlantic Ocean to the Mediterranean Sea through the Strait of Gibraltar varies from $0.9 \times 10^{4}$ to $1.0 \times 10^{4} \mathrm{~mol} \mathrm{C} \mathrm{s}^{-1}$ (or $0.28 \times 10^{12}$ to $0.35 \times 10^{12} \mathrm{~mol} \mathrm{C} \mathrm{year}^{-1}$, respectively). This estimate suggests that the TOC inflow and outflow through the Strait of Gibraltar are two and three orders of magnitude higher than reported via the Turkish Straits and Mediterranean River inputs. (c) 2001 Elsevier Science B.V. All rights reserved.

Keywords: TOC; Distribution; Balance; Apparent oxygen utilisation; The Strait of Gibraltar

\section{Introduction}

The exchange between the Mediterranean and Atlantic through the Strait of Gibraltar is a key issue

\footnotetext{
* Corresponding author. Present address: Center for Marine Science, University of North Carolina at Wilmington, One Marvin K. Moss Lane, Wilmington, NC 28409, USA. Tel.: +1-910-9622361; fax: +1-910-962-2410.

E-mail address: dafnere@uncwil.edu (E.V. Dafner).
}

both for the Mediterranean environment and for global ocean circulation and climate variability (Bryden and Kinder, 1991). It is well known that the Surface Atlantic Water, which flows into the Mediterranean Sea, causes an increase of productivity in the Alboran Sea (Packard et al., 1988; Minas et al., 1991). It has also been shown that in the Atlantic inflow concentrations of the organic forms of nutrients are higher (Coste et al., 1988) and mineral forms of nutrients are lower (McGill, 1961) than 
within the Mediterranean outflow. Estimates by Greze et al. (1985) suggest that the annual zooplankton inflow from the Atlantic Ocean is twice as high as its outflow from the Mediterranean Sea.

By contrast, little is known yet about the influence of the Mediterranean outflow on the biogeochemistry of the eastern North Atlantic although the physical environment of this phenomenon has received more attention. Over the last decade, it has been found that the salinity and temperature of the Deep Mediterranean waters have increased (Béthoux et al., 1990; Rohling and Bryden, 1992; Francour et al., 1994). There are some simulations of an increase of its influence on the dynamic of the North Atlantic Ocean (Rahmstorf, 1998) and on the climate, in general (Johnson, 1997). To predict an influence of the climate warming on the cycling of the major organic nutrients in the North Atlantic and the Mediterranean Sea, we need to know in what quantity these materials are exchanged between both basins.

Polat and Tugrul (1996) estimated an organic carbon budget for the eastern part of the Mediterranean Sea through the Turkish Straits. In contrast, only indirect estimates of the organic carbon budget exist for the Strait of Gibraltar (Copin-Montégut, 1993). No reports of direct observations of organic carbon distribution and exchange through the Strait of Gibraltar have been presented up to the present. In this paper, we describe the results of total organic carbon (TOC) measurements, in terms of distribution and budget, that were estimated from the samples collected during April 1998 in the Strait of Gibraltar area.

\subsection{Study area}

The Strait of Gibraltar is a narrow and shallow connection between the Atlantic Ocean and the Mediterranean Sea (Fig. 1). The Strait has an eastwest orientation, a $60-\mathrm{km}$-long passage with a minimum width of about $12 \mathrm{~km}$ on the Tarifa Narrows, and an average depth of about $600 \mathrm{~m}$. Thirteen kilometres westward of the Tarifa Narrows lies the main bathymetric sill of the Strait, the Camarinal sill, with a maximum depth of about $285 \mathrm{~m}$ and a surface of about $7.86 \mathrm{~km}^{2}$ (Guimerans et al., 1988). Another sill (the Spartel sill) is situated $21 \mathrm{~km}$ west of the

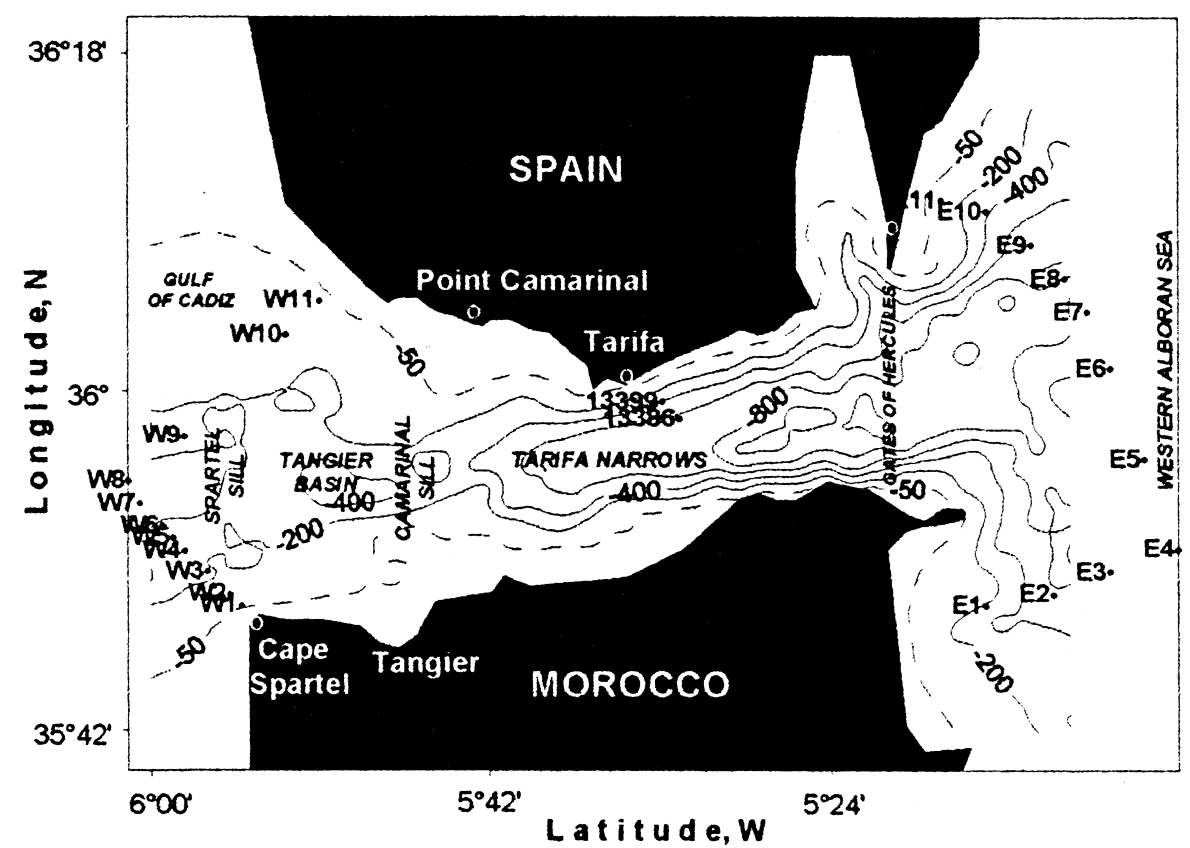

Fig. 1. Bathymetry of the Strait of Gibraltar and stations grid during cruise 232 onboard of the RRV Discovery (12-18 April 1998). To the east of the Strait lies the Alboran Sea, the westernmost basin of the Mediterranean Sea. To the west of the Strait lies the Gulf of Cádiz, an embayment of the Northeast Atlantic Ocean. 
main sill and has a maximum depth of more than $350 \mathrm{~m}$ (La Violette and Lacombe, 1988). Between these two sills, is the Tangier Basin, with a maximum depth of approximately $640 \mathrm{~m}$.

\section{Materials and methods}

\subsection{Field sampling}

Discrete seawater samples were taken from the RRV Discovery (cruise 232) at a series of stations across the Strait of Gibraltar between 12 and 18 of April 1998 (Fig. 1). A CTD rosette system (Seabird) equipped with 101 Niskin bottles was used. Stations were chosen to cover a variety of waters from western (Stn. W1-W11, in the Spartel sill area), and from eastern (Stn. E1-E11, in the Western Alboran Sea) entrances of the Strait, and in the middle of the Strait (Tarifa Narrows, Stn. 13386 and 13399). The bottles were fired at the depths of maximum or minimum distribution of temperature, salinity, oxygen and fluorescence, within and between different water bodies and at the interface layer between the Atlantic inflow and Mediterranean outflow. Samples were taken to within a few meters of the bottom. The positions of the stations are listed in Table 1.

Samples were not filtered and were drawn as soon as possible after the rosette sampler was on the deck of the ship (either first or immediately following the gas samples). The $10 \mathrm{ml}$ samples were collected in duplicate in precombusted $\left(450^{\circ} \mathrm{C}\right.$, at least $\left.6 \mathrm{~h}\right)$ glass ampoules (Wheaton ${ }^{\circledR}$ ). During sampling, seawater was allowed to flow directly from the Niskin stopcock without the stopcock touching the tubes, to reduce the chance of contamination. All ampoules were rinsed three times with the respective sample water before filling to appropriate volumes, poisoned by addition of $\mathrm{HgCl}_{2}\left(10 \mathrm{mg} \mathrm{l}^{-1}\right.$ final concentration) and immediately after filling the ampoules were flame-sealed and stored in the dark.

\subsection{HTCO analysis}

The Shimadzu instrument used in this study was the commercially available Model TOC-5000 Total Carbon Analyzer with quartz combustion column in the vertical position filled with $1.2 \% \mathrm{Pt}$ on silica pillows with approximate diameter of $2 \mathrm{~mm}$ (Cauwet, 1994). The furnace temperature was maintained at $680^{\circ} \mathrm{C}$ and the effluents passed through a mercury trap (gold wire) to remove mercury (Ogawa and Ogura, 1992). A magnesium perchlorate water trap has been added to the system located before the halogen scrubber, and an in-line membrane filter and the nondispersive infrared $\mathrm{CO}_{2}$ detector. Prior to analysis, subsamples were acidified with $10 \mu \mathrm{l}$ of $85 \% \mathrm{H}_{3} \mathrm{PO}_{4}$ to a $\mathrm{pH} \sim 2$ and sparged for $10 \mathrm{~min}$ with $\mathrm{CO}_{2}$-free pure air to remove inorganic carbon as $\mathrm{CO}_{2}$. TOC contamination from the preservation reagent and from the phosphoric acid was below the detection limit. During the sparging procedure, we followed the recommendations of J.H. Sharp (University of Delaware), i.e., care was taken such that during sparging of each sample, seawater did not overflow from the ampoules. This condition was possible at a gas flow rate of $40 \mathrm{ml} \mathrm{min}{ }^{-1}$. One hundred $\mu l$ injections were repeated three to four times for each sample, the analytical precision of the procedure being within $3 \%$, on average. Some variability in values from two different vials gives rise to a lower overall precision (14\%). Prior to analyses of standards and samples, the catalyst bed was "conditioned' by injecting $100 \mu \mathrm{l}$ of acidified and sparged water from a high-quality water purifier, a Millipore Milli-Q Plus ${ }^{\circledR}$ System (hereafter, DW), until the lowest stable integrated area was obtained. To bring the blank down, the catalyst was pretreated by washing in $1 \% \mathrm{HCl}$ and gently rinsed with $\mathrm{DW}$, and dried in a furnace at a temperature of about $450^{\circ} \mathrm{C}$ for 10-15 min. This protocol is different from that used previously, as, for example, heating the catalyst to $500^{\circ} \mathrm{C}$ for $6 \mathrm{~h}$ in a muffle (Skoog et al., 1997).

\subsection{Calibration of the instrument}

Standardisation was carried out every day using potassium hydrogen phthalate (Kanto Chemical) dissolved in DW (3 concentrations) prepared just before sample analyses. The instrument response factor, measured as the slope of the standard addition to DW ( $r^{2}>0.999$ for 19 runs), remained relatively constant and reproducible over the time of analysis. Calibration curves have exhibited little difference in the slope (ave. slope: $6045 \pm 242 \mathrm{area} / \mu \mathrm{M} \mathrm{C}, n=$ 19) and intersect (ave. intersect: $800 \pm 164$ area 
Table 1

Position and depth of the stations, date and time of sampling during the cruise 232 of the RRV Discovery in the Strait of Gibraltar area (4-22 April 1998)

\begin{tabular}{|c|c|c|c|c|}
\hline$N$ stations & Station locations & $\begin{array}{l}\text { Depth } \\
\text { (m) }\end{array}$ & $\begin{array}{l}\text { Sampling date, } \\
\text { April } 1998\end{array}$ & $\begin{array}{l}\text { Time of } \\
\text { sampling }\end{array}$ \\
\hline W1 (13405) & $5^{\circ} 56^{\prime} \mathrm{W}, 35^{\circ} 48^{\prime} \mathrm{N}$ & 128 & 17 & $16 \mathrm{~h} 17 \mathrm{~min}$ \\
\hline W2 (13406) & $5^{\circ} 57^{\prime} \mathrm{W}, 35^{\circ} 49^{\prime} \mathrm{N}$ & 208 & 14 & $17 \mathrm{~h} 19 \mathrm{~min}$ \\
\hline W3 (13412) & $5^{\circ} 58^{\prime} \mathrm{W}, 35^{\circ} 51^{\prime} \mathrm{N}$ & 356 & 18 & $12 \mathrm{~h} 03 \mathrm{~min}$ \\
\hline W4 (13411) & $5^{\circ} 59^{\prime} \mathrm{W}, 35^{\circ} 52^{\prime} \mathrm{N}$ & 424 & 18 & $10 \mathrm{~h} 06 \mathrm{~min}$ \\
\hline W5 (13410) & $5^{\circ} 59^{\prime} \mathrm{W}, 35^{\circ} 54^{\prime} \mathrm{N}$ & 126 & 18 & $09 \mathrm{~h} 04 \mathrm{~min}$ \\
\hline W6 (13407) & $6^{\circ} 00^{\prime} \mathrm{W}, 35^{\circ} 55^{\prime} \mathrm{N}$ & 207 & 17 & $19 \mathrm{~h} 19 \mathrm{~min}$ \\
\hline W7 (13408) & $6^{\circ} 01^{\prime} \mathrm{W}, 35^{\circ} 56^{\prime} \mathrm{N}$ & 274 & 17 & $20 \mathrm{~h} 27 \mathrm{~min}$ \\
\hline W8 (13403) & $6^{\circ} 01^{\prime} \mathrm{W}, 35^{\circ} 57^{\prime} \mathrm{N}$ & 202 & 16 & $22 \mathrm{~h} 49 \mathrm{~min}$ \\
\hline W9 (13402) & $5^{\circ} 58^{\prime} \mathrm{W}, 35^{\circ} 59^{\prime} \mathrm{N}$ & 172 & 16 & $21 \mathrm{~h} 20 \mathrm{~min}$ \\
\hline W10 (13401) & $5^{\circ} 55^{\prime} \mathrm{W}, 36^{\circ} 05^{\prime} \mathrm{N}$ & 115 & 16 & $20 \mathrm{~h} 11 \mathrm{~min}$ \\
\hline W11 (13400) & $5^{\circ} 53^{\prime} \mathrm{W}, 36^{\circ} 04^{\prime} \mathrm{N}$ & 82 & 16 & $19 \mathrm{~h} 05 \mathrm{~min}$ \\
\hline 13386 & $5^{\circ} 32^{\prime} \mathrm{W}, 35^{\circ} 58^{\prime} \mathrm{N}$ & 668 & 13 & $14 \mathrm{~h} 45 \mathrm{~min}$ \\
\hline 13399 & $5^{\circ} 33^{\prime} \mathrm{W}, 35^{\circ} 59^{\prime} \mathrm{N}$ & 557 & 15 & $01 \mathrm{~h} 00 \mathrm{~min}$ \\
\hline E1 (13397) & $5^{\circ} 16^{\prime} \mathrm{W}, 35^{\circ} 51^{\prime} \mathrm{N}$ & 128 & 13 & $22 \mathrm{~h} 16 \mathrm{~min}$ \\
\hline E2 (13396) & $5^{\circ} 12^{\prime} \mathrm{W}, 35^{\circ} 51^{\prime} \mathrm{N}$ & 437 & 13 & $20 \mathrm{~h} 55 \mathrm{~min}$ \\
\hline E3 (13395) & $5^{\circ} 09^{\prime} \mathrm{W}, 35^{\circ} 52^{\prime} \mathrm{N}$ & 432 & 13 & $19 \mathrm{~h} 28 \mathrm{~min}$ \\
\hline E4 (13394) & $5^{\circ} 05^{\prime} \mathrm{W}, 35^{\circ} 54^{\prime} \mathrm{N}$ & 457 & 13 & $17 \mathrm{~h} 59 \mathrm{~min}$ \\
\hline E5 (13393) & $5^{\circ} 07^{\prime} \mathrm{W}, 35^{\circ} 58^{\prime} \mathrm{N}$ & 521 & 13 & $16 \mathrm{~h} 21 \mathrm{~min}$ \\
\hline E6 (13392) & $5^{\circ} 09^{\prime} \mathrm{W}, 36^{\circ} 01^{\prime} \mathrm{N}$ & 562 & 13 & $14 \mathrm{~h} 38 \mathrm{~min}$ \\
\hline E7 (13391) & $5^{\circ} 10^{\prime} \mathrm{W}, 36^{\circ} 04^{\prime} \mathrm{N}$ & 828 & 13 & $12 \mathrm{~h} 42 \mathrm{~min}$ \\
\hline E8 (13390) & $5^{\circ} 11^{\prime} \mathrm{W}, 36^{\circ} 06^{\prime} \mathrm{N}$ & 797 & 14 & $10 \mathrm{~h} 46 \mathrm{~min}$ \\
\hline E9 (13383) & $5^{\circ} 14^{\prime} \mathrm{W}, 36^{\circ} 07^{\prime} \mathrm{N}$ & 650 & 12 & $12 \mathrm{~h} 28 \mathrm{~min}$ \\
\hline E10 (13382) & $5^{\circ} 16^{\prime} \mathrm{W}, 36^{\circ} 09^{\prime} \mathrm{N}$ & 357 & 12 & $10 \mathrm{~h} 30 \mathrm{~min}$ \\
\hline E11 (13381) & $5^{\circ} 18^{\prime} \mathrm{W}, 36^{\circ} 10^{\prime} \mathrm{N}$ & 158 & 12 & $09 \mathrm{~h} 10 \mathrm{~min}$ \\
\hline
\end{tabular}

Number of the stations in the brackets correspond to numeration of the stations in the list of the RRV Discovery.

units, $n=19)$. The bias between slopes was approximately within $4 \%$.

The accuracy and the system blank of our instrument were determined by analysis of the Deep Atlantic Water (DAW) reference and low carbon water (LCW) from ampoules provided by J.H. Sharp. The average dissolved organic carbon (DOC) concentration in the DAW reference and in the $\mathrm{LCW}$ were $45 \pm 1 \mu \mathrm{M} \mathrm{C}, n=19$ and $3 \pm 1 \mu \mathrm{M} \mathrm{C}, n=3$, respectively. Generally, there was no significant difference in peak areas between DW samples and the LCW standards. Individual DW blanks were rechecked after every two to four sea sample injections and were found to be about of $685 \pm 198$ area units, $n=153$. Statistical analysis (ANOVA) showed no difference in the peak areas between DW blanks and LCW standards (Student's $t$-test was 0.13, $p<$ 0.05 , critical value of $t$ at $p=0.05$ was 4.3$)$. TOC concentrations in sea samples were calculated on the basis of the DW blank by averaging all replicate injections of samples, subtracting the average DW value as the total blank and dividing by the slope of the standardisation curve. Our results in the most recent DOC method intercalibration, conducted by Sharp (1994); Sharp et al. (1995), were in agreement with other analysts (J.H. Sharp, personal communication). Therefore, we have confidence that TOC concentrations presented in this report have been determined within an acceptable error of $3 \pm 1 \mu \mathrm{M}$ C.

\section{Results and discussion}

\subsection{Hydrography}

A classical model of water masses exchange through the Strait suggests that two water masses flow through the Strait: Surface Atlantic Water (SAW), which spreads to the Mediterranean Sea, and 
(a)

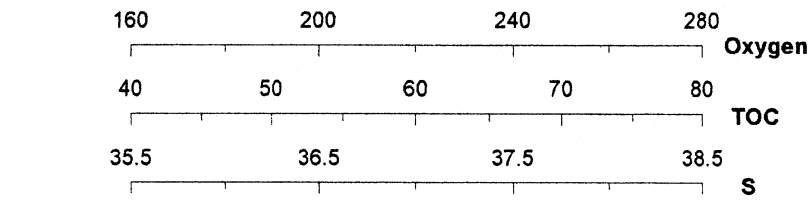

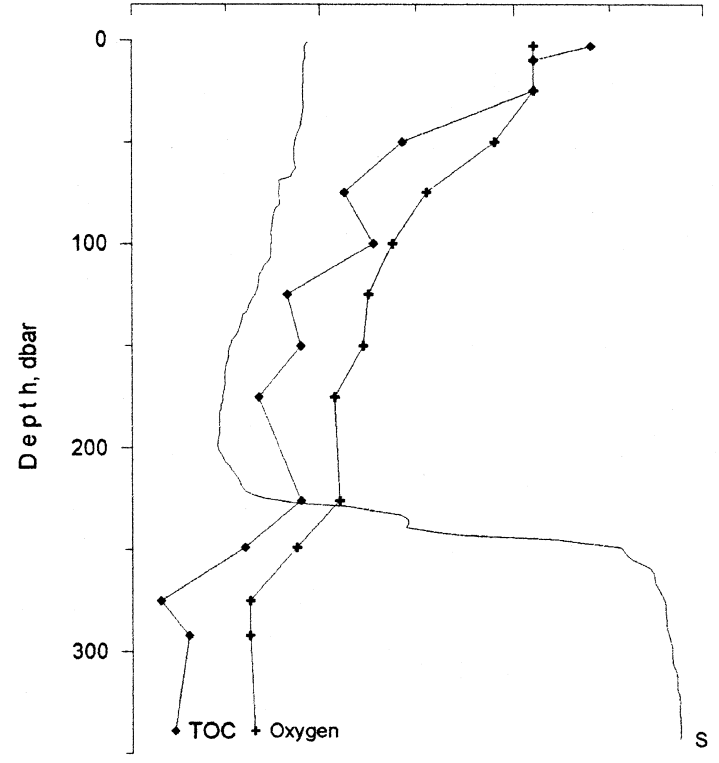

(c)

\begin{tabular}{|cccccc}
160 & & 200 & 240 & 280 \\
\hline 40 & 50 & 60 & & 70 & 80 \\
\hline 35.5 & & 36.5 & & 37.5 & 38.5 \\
\hline
\end{tabular}

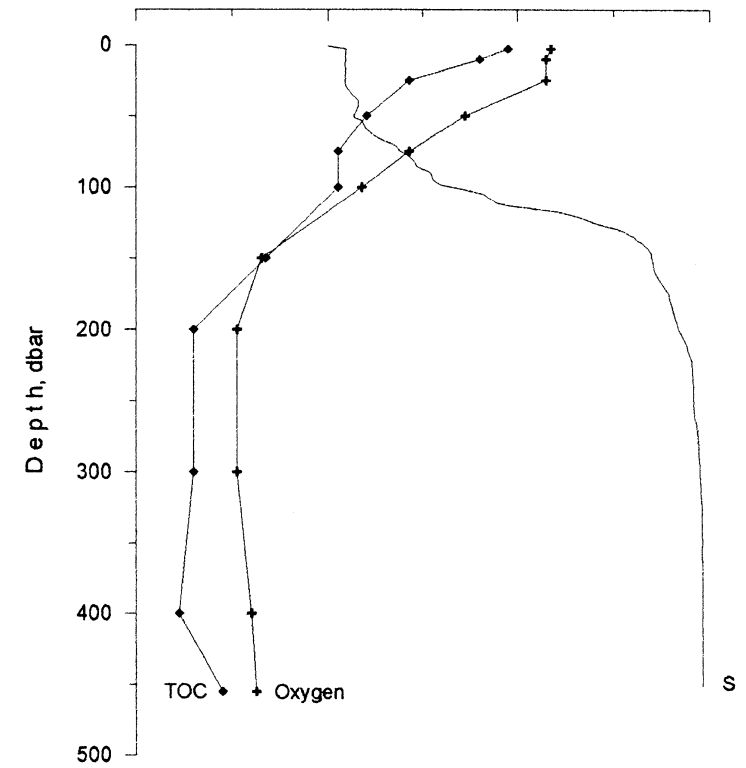

(b)

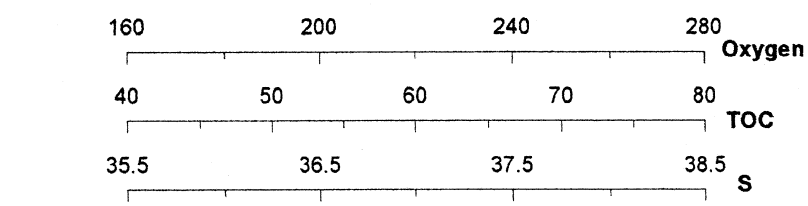

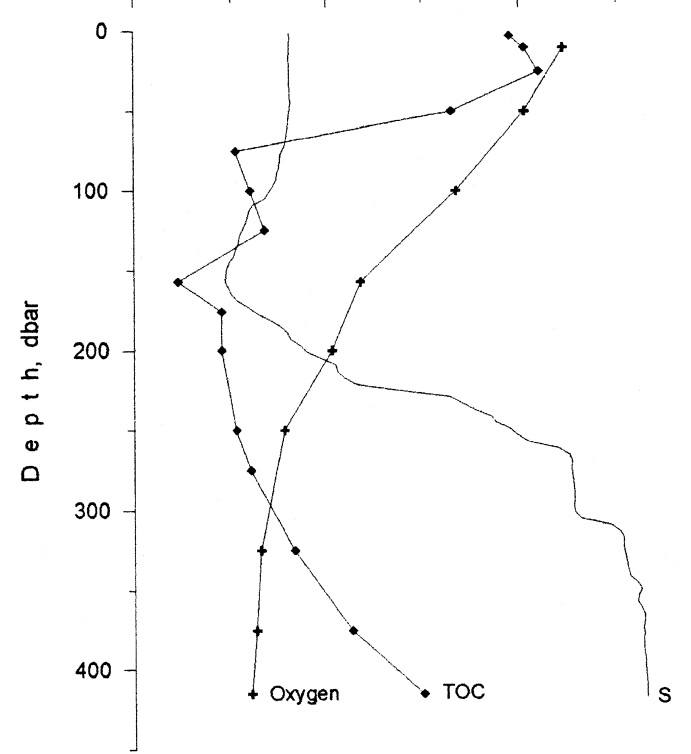

(d)

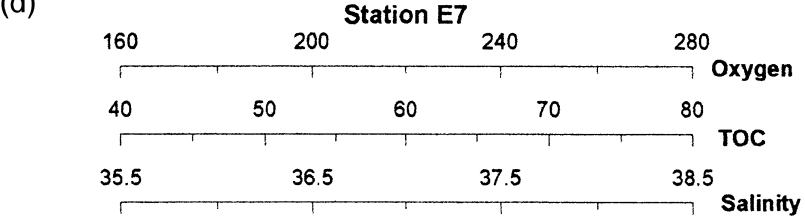

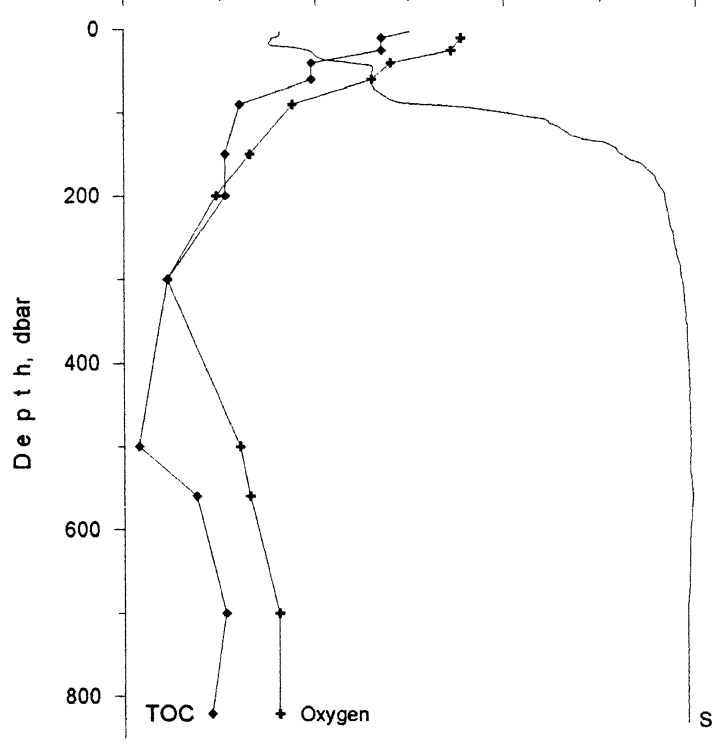

Fig. 2. Typical four vertical profiles of salinity, oxygen $\left(\mu \mathrm{M} \mathrm{kg}^{-1}\right)$ and TOC ( $\left.\mu \mathrm{M} \mathrm{C}\right)$ from the western (Sts. W3, W4) and eastern (Sts. E4, E7) sides of the Strait of Gibraltar. Minimum salinity from the western entrance of the Strait correspond to NACW. Minimum oxygen at Stn. E7 is characterised the residual core of LIW. 
Mediterranean Water, which outflows from the Mediterranean Sea. Inflow slightly exceeds outflow to balance the net loss from the excess of evaporation in the Mediterranean Sea over the sum of precipitation and river discharges. The interaction of these water masses produces an extremely strong halocline (Fig. 2), which allows identification of a third, a transition or interface layer in between (Wes- son and Gregg, 1994; Bray et al., 1995). Tables 2 and 3 give some characteristics of the water masses found within the Strait in April of 1998, and Fig. 3 depicts distributions of salinity along both sections.

The Atlantic inflow in the Gulf of Cádiz is formed by the mixing of the SAW (salinity about of 36.46), North Atlantic Central Water (NACW, salinity less than 36.06), and Spanish Coastal Water with salinity
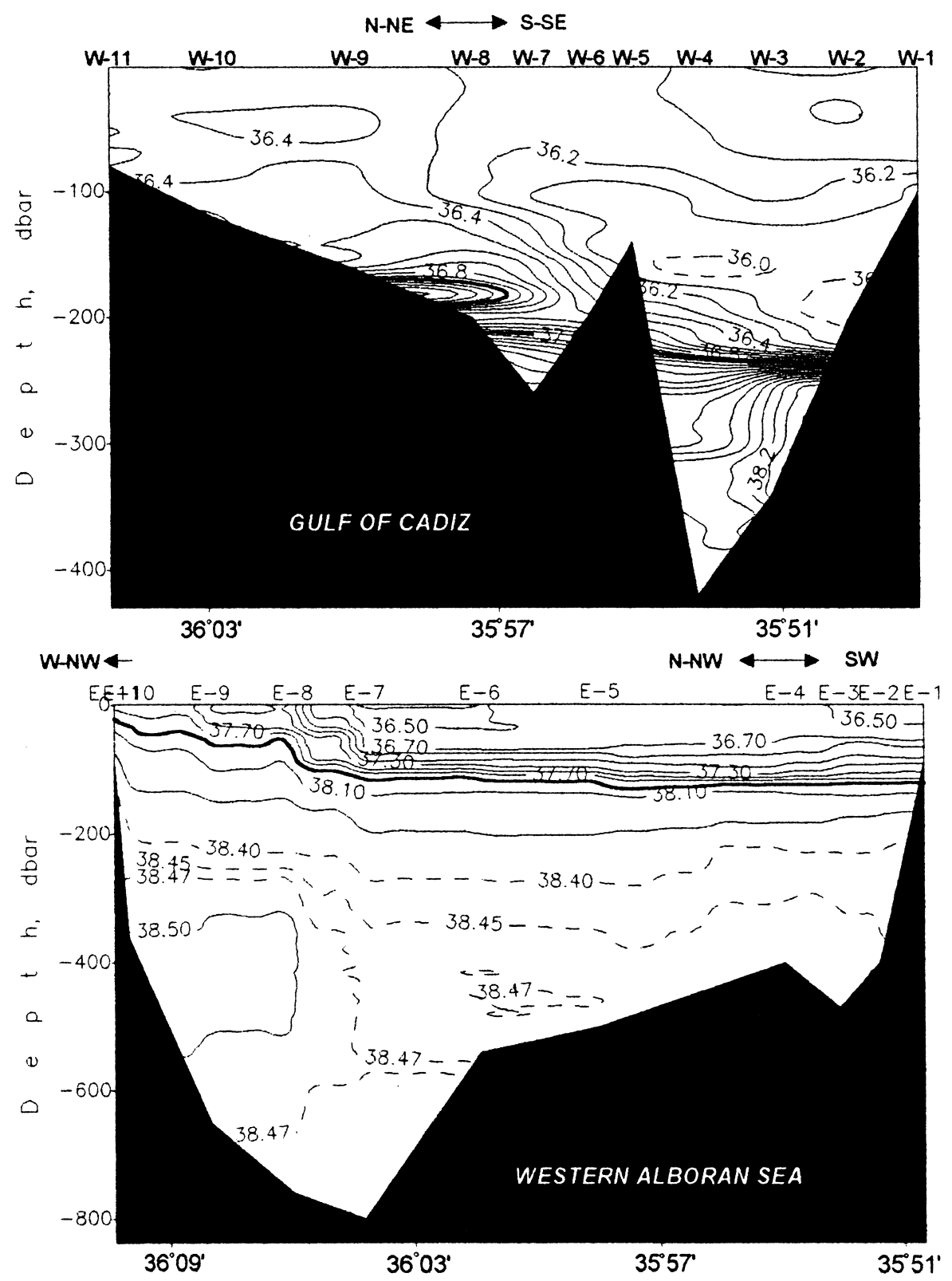

Fig. 3. Distribution of salinity on western (Gulf of Cádiz) and eastern (Western Alboran Sea) entrances of the Strait of Gibraltar. Hereafter, the bottom represents the depth observed at each station and is not typical bathymetric profiles. 


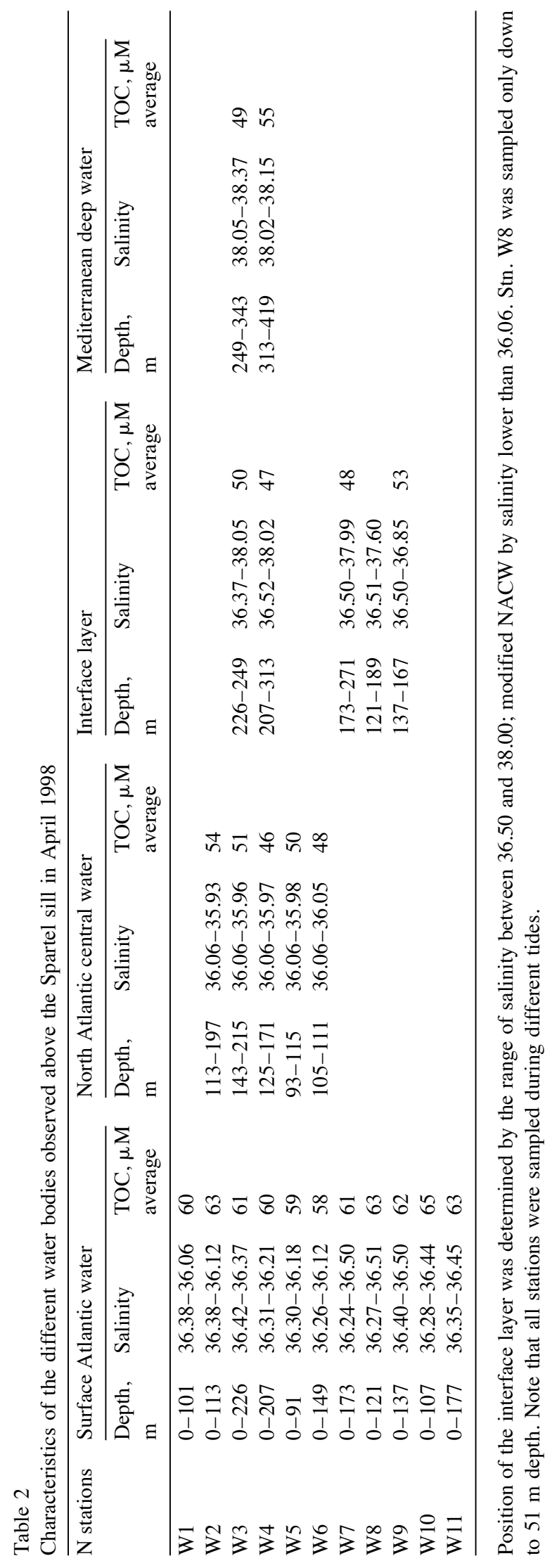


$<36.10$ (Van Geen and Boyle, 1989; Van Geen et al., 1988, 1991). The thickness of SAW in the Strait is highly variable and in April 1998 it decreased from about $100 \mathrm{~m}$ south of the Spartel sill (Table 2) to about $40-55 \mathrm{~m}$ at the Tarifa Narrows and to about $15-40 \mathrm{~m}$ in the Western Alboran Sea (Table 3).

The interface layer is defined by a well-developed halocline with a change in salinity of about 2.00 (Fig. 2). For identification of the interface layer, Lacombe and Richez (1982) have suggested a range of salinity values between 37.00 and 37.50. Bryden et al. (1989) have characterised this layer in the southern part of the Camarinal sill by a salinity range of 36.50-38.00. The interface layer was found to be deeper, thicker, fresher and colder on the west of the Strait (Table 2). The shallowest position of this layer was found in the Western Alboran Sea, where it continued to get saltier and warmer (Table 3 ).

The Mediterranean outflow is marked by a high salinity and temperature, and is formed by the mixing of Levantine Intermediate Water (LIW) and Western Mediterranean Deep Water (WMDW). The LIW originates in the Eastern Mediterranean and is characterised by an intermediate maximum in temperature (about $13.15^{\circ} \mathrm{C}$ ) and salinity (about 38.47 )
(Parrilla and Kinder, 1987). The residual LIW is found preferentially in the northwestern part of the Alboran Sea in a depth band of 200-600 $\mathrm{m}$ and is essentially absent near the African coast. As shown in Fig. 3 and Table 3, we observed the salinity values close to those listed above in April 1998 at the eastern section at Stn. E6 to E10, and at the Tarifa Narrows. WMDW is characterised by a decrease in salinity and temperature (38.42-38.44 and $<12.90^{\circ} \mathrm{C}$ ). WMDW is formed by the winter convection in the south of France (Medoc Group, 1970; Stommel, 1972). The salinity distribution in Fig. 3 demonstrates that in the Western Alboran Sea, values of salinity in the near-bottom layer were always higher than those observed for WMDW. Diluted WMDW (salinity of about 38.45) was only found at the southern most stations E5 to E2. A similar situation, which indicates a small contribution of WMDW to the outflow, has been described previously by Roether and Weiss (1975), Measures and Edmond (1988) and Minas et al. (1991).

The water exchange through the Strait is under the influence of periodic forces, such as tides ( $\mathrm{La}$ Violette and Lacombe, 1988), and nonperiodic forces, such as atmospheric pressure (Stanton, 1983), wind

Table 3

Characteristics of the different water bodies observed at the Tarifa Narrows (Stn. 13386 and 13399), and at the Western Alboran Sea in April 1998

\begin{tabular}{|c|c|c|c|c|c|c|c|c|c|}
\hline \multirow[t]{2}{*}{$\mathrm{N}$ stations } & \multicolumn{3}{|c|}{ Surface Atlantic water } & \multicolumn{3}{|c|}{ Interface layer } & \multicolumn{3}{|c|}{ Mediterranean deep water } \\
\hline & $\begin{array}{l}\text { Depth, } \\
\mathrm{m}\end{array}$ & Salinity & $\begin{array}{l}\text { TOC, } \mu \mathrm{M} \\
\text { average }\end{array}$ & $\begin{array}{l}\text { Depth, } \\
\mathrm{m}\end{array}$ & Salinity & $\begin{array}{l}\text { TOC, } \mu \mathrm{M} \text { average } \\
\text { average }\end{array}$ & $\begin{array}{l}\text { Depth, } \\
\mathrm{m}\end{array}$ & Salinity & $\begin{array}{l}\text { TOC, } \mu \mathrm{M} \\
\text { average }\end{array}$ \\
\hline 13386 & $0-55$ & $36.29-36.51$ & 54 & $55-110$ & $36.51-37.98$ & 46 & $110-549$ & $37.98-38.47$ & 39 \\
\hline 13399 & $0-41$ & $36.34-36.54$ & 61 & $41-100$ & $36.54-38.00$ & 48 & $100-611$ & $38.00-38.48$ & 41 \\
\hline E1 & $0-63$ & $36.51-36.80$ & 64 & $63-85$ & $36.80-37.01$ & 60 & & & \\
\hline E2 & $0-29$ & $36.35-36.51$ & 63 & $29-127$ & $36.51-38.01$ & 59 & $127-435$ & $38.01-38.45$ & 47 \\
\hline E3 & $0-45$ & $36.51-36.60$ & 60 & $45-133$ & $36.60-38.02$ & 56 & $133-459$ & $38.02-38.46$ & 44 \\
\hline E4 & $0-31$ & $36.50-36.60$ & 63 & $31-129$ & $36.60-38.01$ & 55 & $129-451$ & $38.01-38.46$ & 45 \\
\hline E5 & $0-45$ & $36.59-36.61$ & 61 & $45-135$ & $36.61-38.02$ & 54 & $135-519$ & $38.02-38.47$ & 45 \\
\hline E6 & $0-67$ & $36.46-36.54$ & 54 & $67-113$ & $36.54-38.01$ & 50 & $113-557$ & $38.01-38.47$ & 41 \\
\hline E7 & $0-33$ & $36.28-36.51$ & 59 & $33-135$ & $36.51-38.02$ & 51 & $135-831$ & $38.02-38.45$ & 45 \\
\hline E8 & $0-17$ & $36.96-37.10$ & 66 & $17-77$ & $37.10-38.01$ & 52 & $77-789$ & $38.01-38.46$ & 42 \\
\hline E9 & $0-15$ & $37.59-37.60$ & 58 & $15-85$ & $37.60-38.00$ & 53 & $85-675$ & $38.00-38.48$ & 44 \\
\hline E10 & $0-37$ & $37.54-38.00$ & 65 & $37-135$ & $38.00-38.40$ & 50 & $135-353$ & $38.40-38.48$ & 46 \\
\hline E11 & $0-37$ & $37.84-38.10$ & 55 & $37-71$ & $38.10-38.33$ & 47 & $71-111$ & $38.33-38.40$ & 46 \\
\hline
\end{tabular}

Positions of the basis of SAW and the interface layer were determined by the phenomenological criteria (vertical distribution of salinity) individually for each station. Note that all stations were sampled during different tides. 
stress over the west Mediterranean Sea and the Gulf of Cádiz (Gründlich, 1981), formation of the WMDW during the winter convection, and features of the Alboran Gyre circulation (Bryden and Stommel, 1982). As a result, the water flow in the Strait does not move in the form of continuous currents but as tidal-induced pulses, which vary in the amount of water they contain according to the daily and monthly variation in the above-mentioned factors.

\subsection{TOC vertical distribution}

All data from the Strait of Gibraltar are presented along two sections in Fig. 4: western (Gulf of Cádiz) and eastern (Western Alboran Sea). Both these sections have been characterised by similar features of TOC distribution: (i) a decrease of TOC content from the Gulf of Cádiz towards the Alboran Sea; (ii) an increase of TOC concentrations in the Atlantic

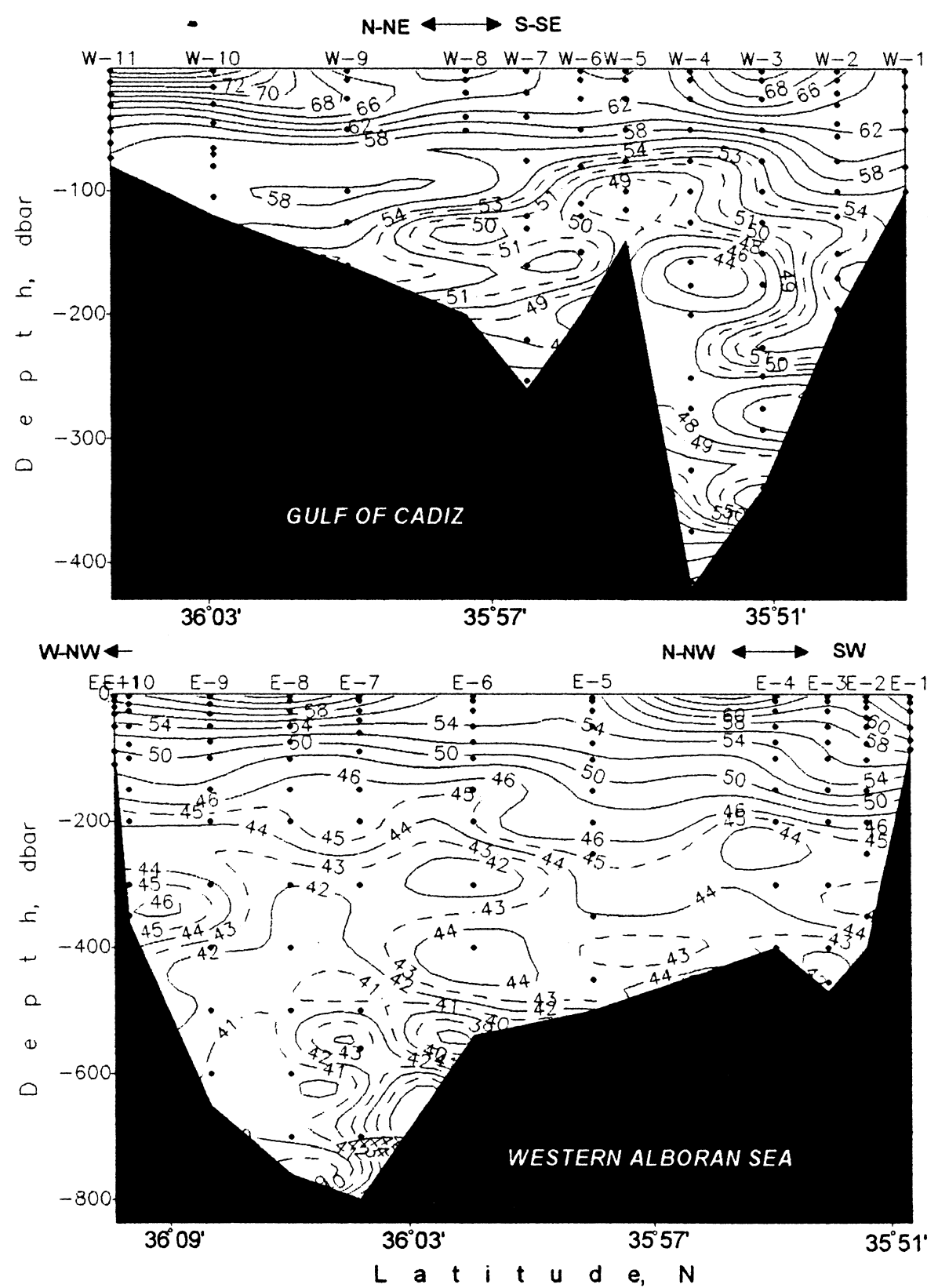

Fig. 4. TOC contour plots ( $\mu$ M C) along western (Gulf of Cádiz) and eastern (Western Alboran Sea) entrances of the Strait of Gibraltar. 
inflow from the middle of the sections towards the continents; (iii) a decrease of TOC concentrations from the Atlantic inflow to the Mediterranean outflow, and (iv) a patchiness of TOC inventory ( $\mu \mathrm{M}$ C) below the Atlantic inflow. This patchiness was due either to sampling during different times of the tide, particularly in the Gulf of Cádiz, or to different composition of the water layers from both sides of the Strait. In the Western Alboran Sea, water column was composed only by SAW, Mediterranean waters and the interface layer in between. Figs. 2 and 3, and Table 2 show that at several stations above the Spartel sill (Stn. W2-W6) additionally modified NACW was observed.

We summarize all measurements in one vertical profile (Fig. 5), which shows a large scatter of TOC concentrations in the upper $200 \mathrm{~m}(50-79 \mu \mathrm{M} \mathrm{C})$ including SAW, NACW, interface layer and upper Mediterranean waters, and a decrease down to 38-48 $\mu \mathrm{M} \mathrm{C}$ in deep waters. At several depths, the scatter is due to joining (into one profile) near-bottom measurements from the Gulf of Cádiz and pelagic observations from the same depth from the Western Alboran Sea. Some of the stations from both sides of the Strait (W4, W5, W11 and E2, E3, E4, E5, E7, E10) were characterised by an increase of TOC concentrations in the near-bottom layer (Stn. W4 and E4 in Fig. 4), which could be a result of bottom sediment resuspension.

\subsection{TOC sources in the Atlantic inflow}

The increase of TOC concentrations from the middle of the sections towards Spain and Morocco

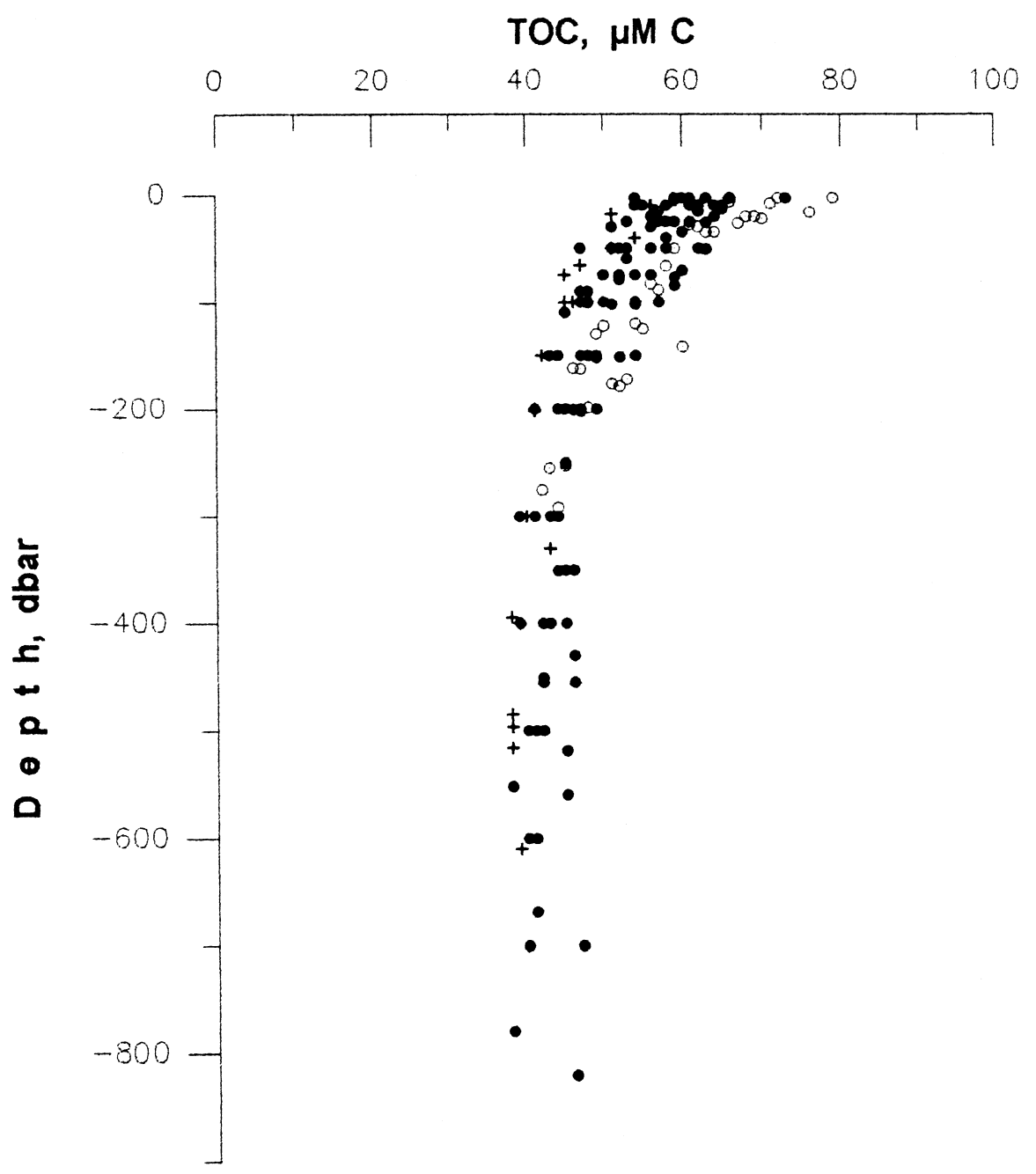

Fig. 5. Integrated TOC profile from Tarifa Narrows $(+)$, western $(\bigcirc)$ and eastern

) entrances of the Strait of Gibraltar. 
indicate an accumulation of organic carbon along continents. Having only oxygen and fluorescence (in Volts) data, we can only hypothesize that the sources of TOC accumulation are either production of organic carbon in situ, or Atlantic inflow already enriched in organic carbon during its flow to the Strait.

In situ production can be induced by upwelling since such phenomenon, already reported between Gibraltar and the Bay of Malaga (including northeastern part of the strait), may affect the northwestern Alboran Sea (Cano, 1978; Gil and Gomiz, 1994; Rodríguez et al., 1998). Minas et al. (1991) used diagram analysis for study of water exchange through the Strait and demonstrated that in the upwelling area along the Spanish coast, nutrients are largely transported to the photic layer. They concluded that this process is responsible for bioproductivity increase along the Spanish coast and for formation of the Alboran oxygen minimum. As seen from distribution of salinity in Fig. 3, this upwelling is found in the northern part of the eastern section between stations E11 and E8. At these stations, we did not observe oxygen oversaturation (Fig. 6), but we found increased TOC concentrations up to $73 \mu \mathrm{M} \mathrm{C}$. This suggests that higher TOC concentrations in proximity of Gibraltar (Stn. E11-E8) were due to organic material accumulation very likely produced in the northeastern part of the strait rather than local phytoplankton production. Fig. 6 shows also a slight oxygen oversaturation of the surface layer along the

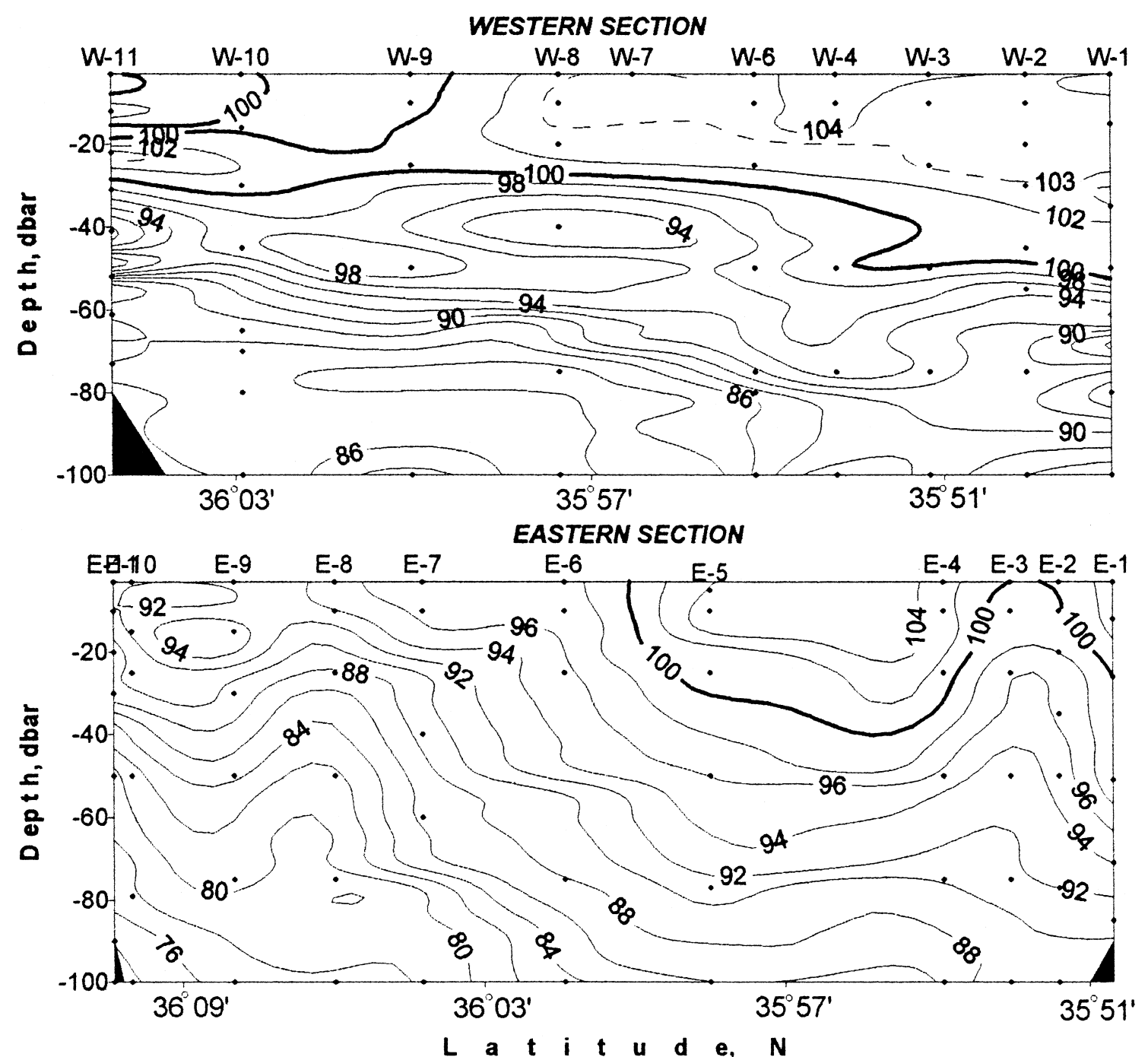

Fig. 6. Oxygen saturation (\%) in the upper $100 \mathrm{~m}$ layer. Note that the area between Stn. E8-E10 was characterised by upwelling. 
western section (up to $4 \%$ ) and in the southern part of the eastern section (Stn. E1-E5, up to 5\%). As indicated by Fig. 4, these areas are also characterised by high TOC concentrations that allow us to hypothesize on production of organic carbon by phytoplankton.

However, Atlantic inflow may also explain some high TOC concentrations observed in the Strait. In their paper on trace metal studies in the Atlantic inflow, Van Geen et al. (1988) have shown that high trace-metal concentrations in the surface water of the Alboran Sea may be due to enriched Atlantic waters flowing into the Mediterranean Sea through the Gulf of Cádiz. Our recent results indicate high DOC concentrations (up to $89 \mu \mathrm{M} \mathrm{C}$ ) in the Gulf of Cádiz even during the winter season (Dafner et al., 1999). This high DOC concentration level might be due to resuspension of fresh bottom fluff settled during the last productive cycle or terrestrial input. In this case, the hypothesis of TOC enrichment in the Gulf of Cádiz due to TOC-rich Atlantic waters cannot be precluded.

\subsection{TOC pool in the Mediterranean outflow}

The origin of the Mediterranean outflow is an unresolved question among physical oceanographers. There is the evidence that at the time of our observations, LIW contributed to the outflow (Section 3.1) although at the southern stations (E2-E5) we have observed diluted WMDW with salinity values of about 38.45-38.46. According to extensive hydrological observations from the literature, the outflow seems to fluctuate between waters rich in LIW and waters rich in WMDW. One permanent characteristic of LIW is an oxygen minimum (Fig. 4, Stn. E7), which is located mainly in the northern sector of Alboran anticyclonic gyre and related to increased productivity in the Atlantic inflow (Packard et al., 1988; Minas et al., 1991). The upwelling in the northwestern part of the Alboran Sea and the resulting plankton growth prove that a potential source of organic matter, which is required to sustain an enhanced oxygen utilisation rate.

The lowest TOC concentrations observed in the Western Alboran Sea suggest that the refractory pool of organic carbon in the LIW is likely to range from 38 to $42 \mu \mathrm{M} \mathrm{C}$. This estimate is slightly lower than the $44-52 \mu \mathrm{M} \mathrm{C}$ that was recently presented for this water in the Catalan-Balearic Sea (Doval et al., 1999) and the Alboran Sea (Sempéré et al., unpublished observation). The renewal time-scale of water masses, which form the Mediterranean outflow ranges from 7-10 (Andrie and Merlivat, 1988; Christensen et al., 1990) to 100 years (Lacombe et al., 1981; Gascard and Richez, 1985) for the WMDW, and from 10 to 20 years for the LIW (Stratford and Williams, 1997). Although LIW is younger than deep oceanic waters, the TOC values reported here are close to those measured for the very old deep ocean waters (Hansell and Carlson, 1998). These findings argue for the participation of bacteria turnover of the organic material inside the LIW on its pathway to the Strait of Gibraltar from the Catalan-Balearic Sea. More recently, Packard et al. (1988) have emphasised that metabolic activity, bacterial biomass, and particulate organic material should be higher in the LIW of the Western Alboran Sea than farther to the east, and especially higher than in the LIW of the Balearic Sea.

High TOC concentrations within the Mediterranean outflow (ca. $60 \mu \mathrm{M} \mathrm{C}$ ) were found in the Gulf of Cádiz. Figs. 2 and 4 and show that at Stn. $\mathrm{W} 4$, TOC concentrations increased from $51 \mu \mathrm{M} \mathrm{C}$ at the depth of $325 \mathrm{~m}$ to $60 \mu \mathrm{M} \mathrm{C}$ in the near-bottom layer (415 m). Armi and Farmer (1989) have observed that the Tangier basin acts as a reservoir of the Mediterranean waters that fills and drains on each tidal cycle. Acoustic Doppler Current Profiler data from our cruise have shown that different layers of the Mediterranean waters in this basin could flow to the west as well as to the east, depending on the tide (A. Benabdeljelil, personal communication, 1998). This feature suggests that before overflowing through the Spartel sill, the Mediterranean outflow could delay for some time within the Tangier basin. As a working hypothesis, we assume that enrichment of the Mediterranean outflow by organic carbon in this basin occurs either via resuspension of bottom sediments or via input of particulate organic carbon from SAW and its deeper resuspension. To check this hypothesis, additional research in the Tangier basin is required.

\subsection{TOC vs. salinity relationship}

The analysis presented in Section 3.2 does not take explicit account of tidal variability in exchange 
Gulf of Cadiz

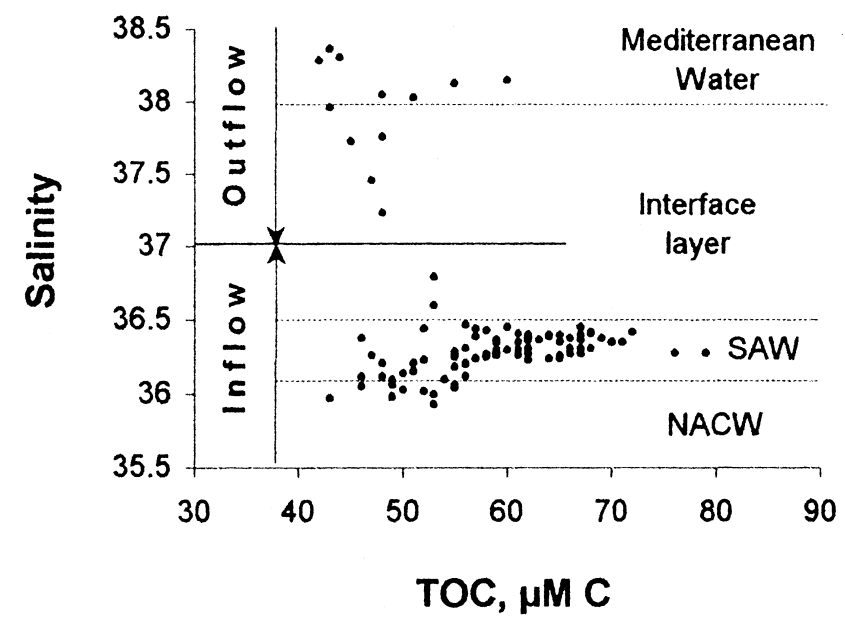

Western Alboran Sea

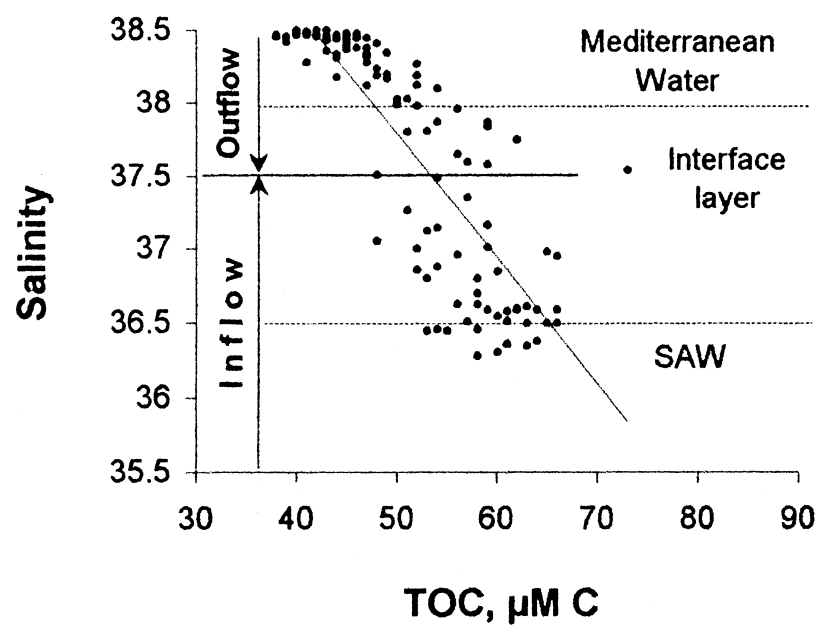

Fig. 7. Scatter plot of TOC concentrations vs. salinity. In the Gulf of Cádiz and at Tarifa Narrows, strong Atlantic inflow is marked by salinity lower than 36.50 , Mediterranean outflow is traced by salinity greater than 38.00 and intermediate salinities depict interface between two layers for which substantial periods of both inflow and outflow. The 37.00 isohaline approximated an average position of the interface layer above the Spartel sill, after (Bryden et al., 1989). In the Western Alboran Sea, the average location of interface layer is shown by the isohaline 37.50. The equation of the regression line in the Western Alboran Sea is $y=-0.085 x+42.04\left(r^{2}=0.69, n=120\right)$.

through the Strait. Most of the outflow occurs in bursts during the semidiurnal tide cycle: when the outflowing tide is strongest, the interface is relatively shallow, so there is a thick layer of the Mediter-

Table 4

Comparison of the slopes of DOC vs. AOU relationship by historical data

\begin{tabular}{|c|c|c|}
\hline Slope & Location & Reference \\
\hline-0.77 & Marine organic matter & Redfield et al. (1963) \\
\hline-0.80 & NW Pacific & Sugimura and Suzuki (1988) \\
\hline-1.00 & Surface & Druffel et al. (1989) \\
\hline-0.21 & Deep Water, N Pacific & \\
\hline-0.062 & NW Indian Ocean & Kumar et al. (1990) \\
\hline-0.24 & Sargasso Sea & Bauer et al. (1990) \\
\hline-1.58 & Surface & Tanoue (1992) \\
\hline \multicolumn{3}{|l|}{-1.08} \\
\hline-0.017 & Deep water, N Pacific & \\
\hline \multicolumn{3}{|l|}{-0.047} \\
\hline-0.21 & N Atlantic Ocean & Kepkay and Wells (1992) \\
\hline \multicolumn{3}{|l|}{-0.25} \\
\hline-0.56 & N Atlantic & $\begin{array}{l}\text { Peltzer et al. (unpublished), } \\
\text { cited by Kepkay and Wells (1992) }\end{array}$ \\
\hline-0.43 & N Atlantic Ocean & De Baar et al. (1993) \\
\hline-0.14 & Equatorial Atlantic Ocean & Thomas et al. (1995) \\
\hline-0.09 & & \\
\hline-0.074 & Surface & Peltzer and Hayward (1996) \\
\hline 0.04 & Deep water, Equatorial Pacific & \\
\hline-0.084 & Indian sector of the Southern Ocean & Wiebinga and De Baar (1998) \\
\hline-0.26 & Pacific sector of the Southern Ocean & Doval and Hansell (2000) \\
\hline-0.23 & Central Indian Ocean & \\
\hline-0.25 & The Strait of Gibraltar & This study \\
\hline
\end{tabular}


ranean waters flowing swiftly over the Camarinal sill. Conversely, on the inflowing tide, the interface is relatively deep, so there is a thick layer of Atlantic water flowing swiftly into the Mediterranean. Such bursts account for more than half of the exchange across the sill between the Atlantic and Mediterranean basins (Bryden et al., 1989; Bray et al., 1995).

To remove discrepancies caused by the tide fluctuations, a relationship between TOC and salinity was developed. Fig. 7 shows several features of this TOC vs. salinity relationship. Firstly, in the Atlantic inflow and Mediterranean outflow, the salinity values were higher in the Western Alboran Sea than in the Gulf of Cádiz. Secondly, a larger scatter of TOC and salinity values was found in the Gulf of Cádiz than in the Western Alboran Sea. According to Bryden et al. (1989), east of the Camarinal sill salinities lower than 36.50 indicate a strong inflow. This layer is characterised by the largest scatter of TOC concentrations ( $48-79 \mu \mathrm{M} \mathrm{C})$. Note that modified NACW was found between SAW and the interface layer or within SAW (Fig. 2, Table 2). This water mass is usually observed only above the Spartel sill and is not involved in water mass exchange through the Strait of Gibraltar, but NACW influences the properties of underlying and overlaying waters due to entrainment (Price et al., 1993). TOC concen-
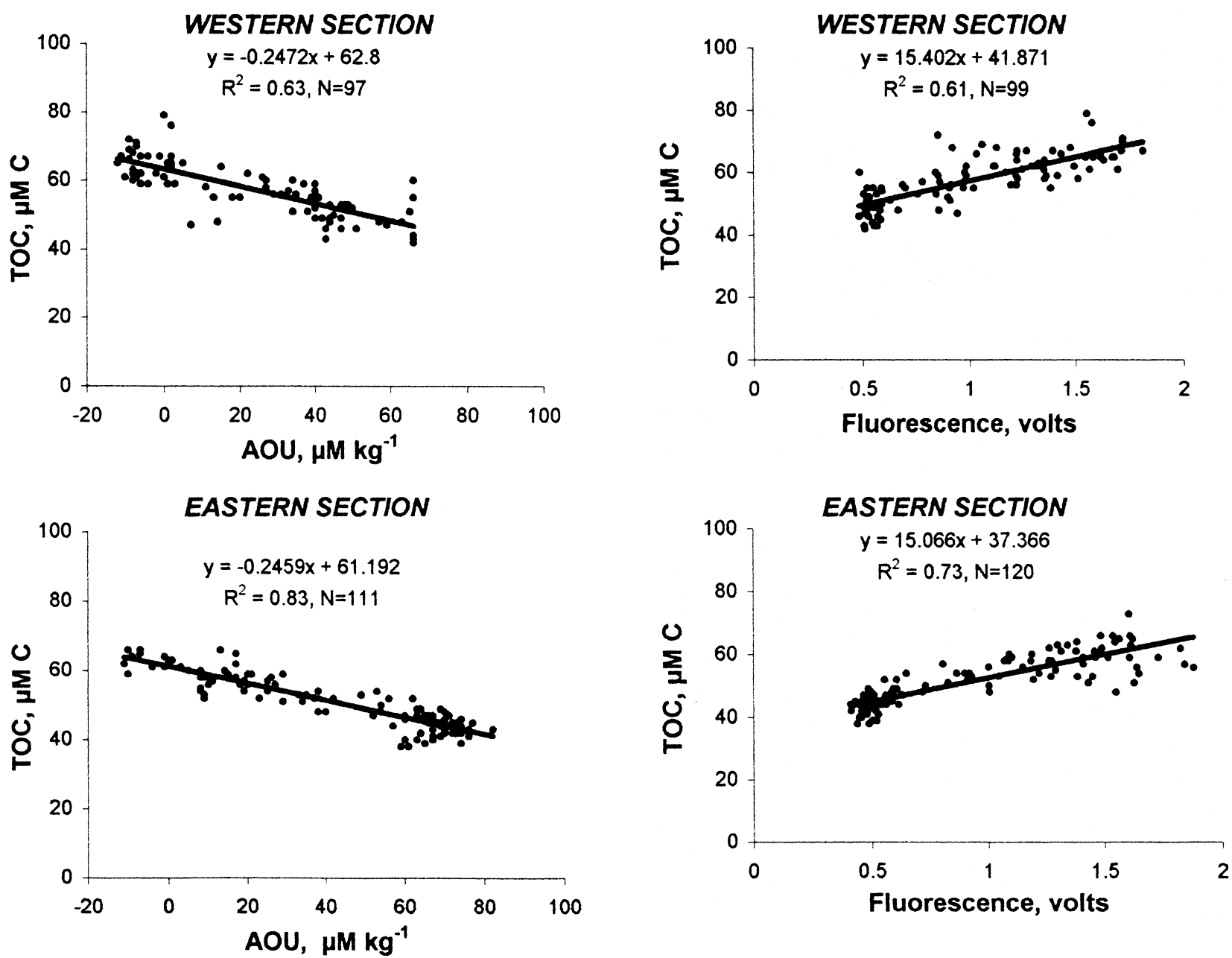

Fig. 8. Composite of TOC vs. AOU, TOC vs. fluorescence, and AOU vs. fluorescence for the western and eastern entrances of the Strait of Gibraltar. 


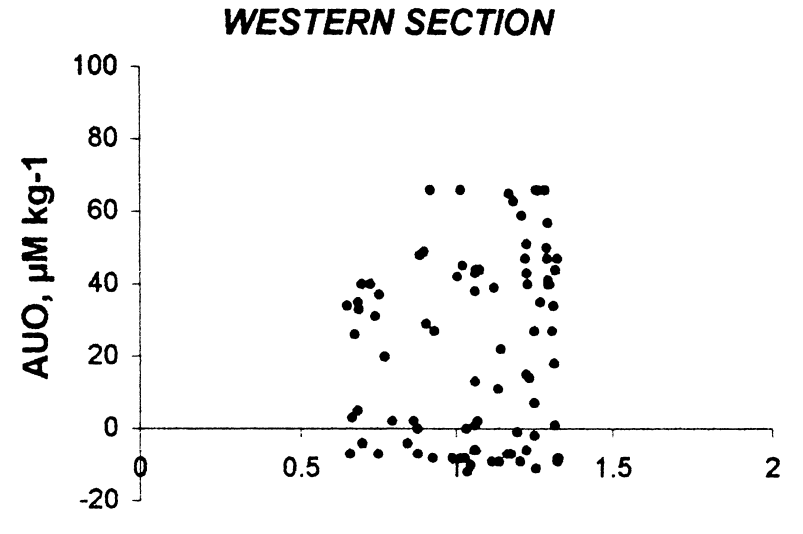

Fluorescence, volts

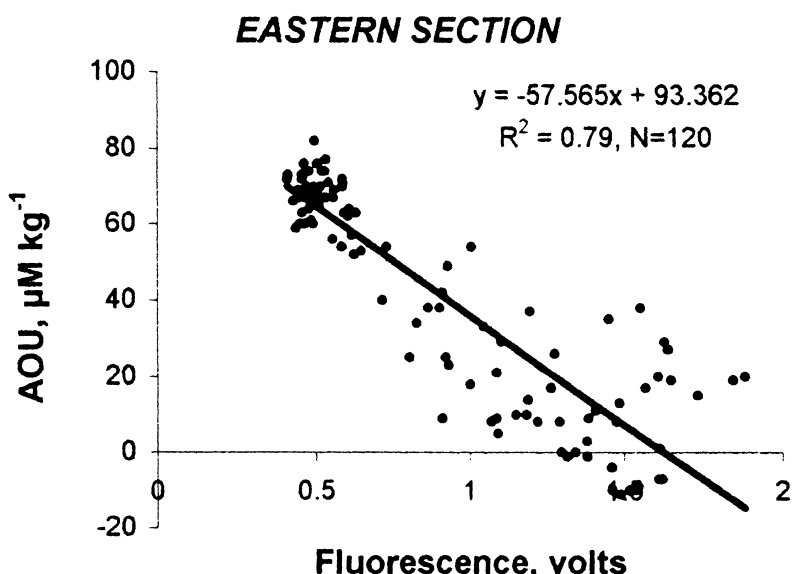

Fig. 8 (continued).

trations in modified NACW ranged from 43 to 55 $\mu \mathrm{M}$ C. In the Western Alboran Sea side, where the Atlantic inflow gets saltier $(>36.50)$ and thicker (down to 15-40 m, Table 3), we observed a lower scatter of both parameters (Fig. 7); consequently, the TOC pool correlates with salinity $\left(r^{2}=0.69, n=\right.$ 120).

For the Mediterranean waters with salinities greater than 38.00 , there is strong outflow. Indeed, the lowest TOC content was found there $(42-60 \mu \mathrm{M}$ $\mathrm{C}$ from the Atlantic Ocean and 38-52 $\mu \mathrm{M} \mathrm{C}$ from the Mediterranean Sea sides). For intermediate salinities, there are substantial periods of both inflow and outflow. This transition zone shows a coincidence of intermediate values of salinity as well as TOC. An average inflow is marked by a salinity lower than 37.00 along the western section and about 37.50 along the eastern section. The transition between inflow and outflow occurs, on average, at a salinity of 37.00 and 37.50, respectively (Fig. 7).

\subsection{Relationships of TOC vs. AOU, TOC vs. fluores- cence and $A O U$ vs. fluorescence}

Recent studies have shown an inverse relation between DOC and apparent oxygen utilisation (AOU, Table 4), since both DOC and oxygen are used by bacteria, which in turn produce $\mathrm{CO}_{2}$ through respiration. In contrast, Martin and Fitzwater (1992) and Hansell et al. (1993) have reported weak or insignificant correlation between DOC and AOU. Our observations, pooling Atlantic inflow and Mediterranean outflow together, show the former correlation. Fig. 8 shows plots of TOC vs. AOU, AOU vs. fluorescence (in Volts), and TOC vs. fluorescence from the eastern and western entrances of the Strait. The slopes and intersects of lines drawn through the data points of TOC vs. AOU (Fig. 8) and TOC vs. fluorescence (Fig. 8) at both sections are quite similar and the differences in correlation, presumably, are due to the different number of observations.

In the Western Alboran Sea, TOC exhibits a positive linear correlation with fluorescence (Fig. 8; $r=0.73, n=120)$ and increased fluorescence values in the SAW are inversely related to AOU (Fig. 8; $r=0.79, n=120$ ). In the Gulf of Cádiz, the relationship of AOU vs. fluorescence, by contrast, exhibits a great scatter (Fig. 8), but the TOC vs. fluorescence relationship is still significant (Fig. 8). A simple comparison between AOU and fluorescence from both sections (Fig. 8) suggests that variability of fluorescence values in the Gulf of Cádiz was lower than in the Eastern Alboran Sea. Large fluorescence scatter from the eastern entrance of the Strait is due primarily to deeper sampling (down to $800 \mathrm{~m}$ to the east and down to $340 \mathrm{~m}$ to the west of the Strait) that explains the scatter of low fluorescence values $(\sim 0.5 \mathrm{~V})$. Secondly, in the Eastern Alboran Sea, higher photosynthetic activities could explain the scatter of high fluorescence values $(>1.5$ V). SAW is almost always easily discernible in the Gulf of Cádiz and in the Alboran Sea in satellite images of chlorophyll a distribution (Minas and Minas, 1993a,b; Antoine et al., 1995).

Historical data on the DOC vs. AOU relationship, summarised in Table 4, suggest a large variability of 
the slope in different areas of the ocean. One of the problems comparing the historical data in Table 4 is that prior to Peltzer and Hayward (1996) all authors used a model I regression causing a negative bias in their slopes in addition to the natural variability. Since then, most authors have used the geometric mean regression (a model II regression). Thus, some of the scatter in the numbers shown in Table 4 is due to the different statistical treatment and we cannot make corrections without the original data.

The major difficulty in interpretation of the relationship of TOC vs. AOU arises from an estimate of the preformed TOC concentrations, while the preformed $\mathrm{AOU}$ is at equilibrium with the atmosphere (Toggweiler, 1989, 1992). Tanoue (1992) have shown that a single linear regression analysis throughout the entire water column was inappropriate for estimations of the contribution of DOC to the utilisation of oxygen in the water column. In general, correlation was found when subsurface and intermediate levels are considered separately, i.e., variations of both AOU (and probably DOC) were as much due to a mixing as to biogeochemical processes (Thomas et al., 1995).

From both sides of the Strait of Gibraltar, we have obtained similar correlations and slopes throughout the entire water column, which lay approximately in middle of the range presented in Table 4. The inverse relationship from the Strait of Gibraltar was linear and the slope of -0.25 was lower than the -0.77 reported by Redfield et al. (1963) for organic matter of average marine composition. From only the vertical profile of both property distributions, it is impossible to conclude if these correlations are due to DOC consumption by bacteria or mixing. To evaluate the contribution of TOC to AOU, an analysis of both these properties along isopycnal surfaces is needed (Doval and Hansell, 2000), which we could not perform in this work due to a poor spatial resolution of sampling and a large variability of the dynamical environments. Theoretically, the slope, which we found in the Strait of Gibraltar area, suggests that bacterial remineralization of organic matter accounts for approximately one-third of the oxygen deficit in surface and deep waters. This value is higher than that reported by Ogawa and Ogura (1992) for the Northwestern Pacific, by Peltzer and Hayward (1996) for the equato- rial Pacific and by Wiebinga and De Baar (1998) for the Indian sector of the Southern Ocean.

\subsection{Organic carbon exchange through the Strait of Gibraltar}

Because of the great variability of the dynamic environment, it is difficult to assign from direct observations mean values of typical water transports for a TOC balance computation. Lacombe and Richez (1982) have pointed out that with the complex spatial and temporal variations of the flow, only approximate values of transport are available. Bryden and Kinder (1988), reviewing historical balance estimations, have concluded that the flows through the Strait are apparently limited 1 to $2 \times 10^{6} \mathrm{~m}^{3} \mathrm{~s}^{-1}$. The new transports through the Strait of Gibraltar are $30 \%$ smaller than historical estimates and, furthermore, tidal oscillations contribute nearly half of the total transport (Bryden and Kinder, 1991). Consequently, for a TOC pool budget calculation, we cannot use general schemes of organic carbon estimation as designed for the open ocean (e.g., Walsh et al., 1992; Peltzer and Hayward, 1996).

Here, we present a TOC budget, which was calculated according to the water transport estimates based on the data of Gibraltar experiment (Bryden et al., 1994; Bray et al., 1995) and CANIGO observations summarised in Fig. 9. The estimate of the TOC transport was made by simply dividing the interface layer according to the salinity values (37.00 and 37.50 from western and eastern entrances of the Strait, respectively) and incorporating the upper part of the interface into the upper layer (Atlantic inflow) and the lower part into the lower layer (Mediterranean outflow). TOC transport in the Atlantic inflow and Mediterranean outflow was calculated as the product of the water transport and the average TOC concentration in each water layer along western and eastern sections and at Tarifa Narrows.

Fig. 9 shows that TOC transport through the Strait varies from $3.7 \times 10^{4}$ to $4.8 \times 10^{4} \mathrm{~mol} \mathrm{C} \mathrm{s}^{-1}$ for the Atlantic inflow and from $2.8 \times 10^{4}$ to $3.8 \times 10^{4}$ mol $\mathrm{C} \mathrm{s}^{-1}$ for the Mediterranean outflow. Differences of TOC transport between Atlantic inflow and Mediterranean outflow give an estimate of TOC balance over the water column, which are in the range of $0.9 \times 10^{4}$ to $1.0 \times 10^{4} \mathrm{~mol} \mathrm{C} \mathrm{s}^{-1}$ (or 


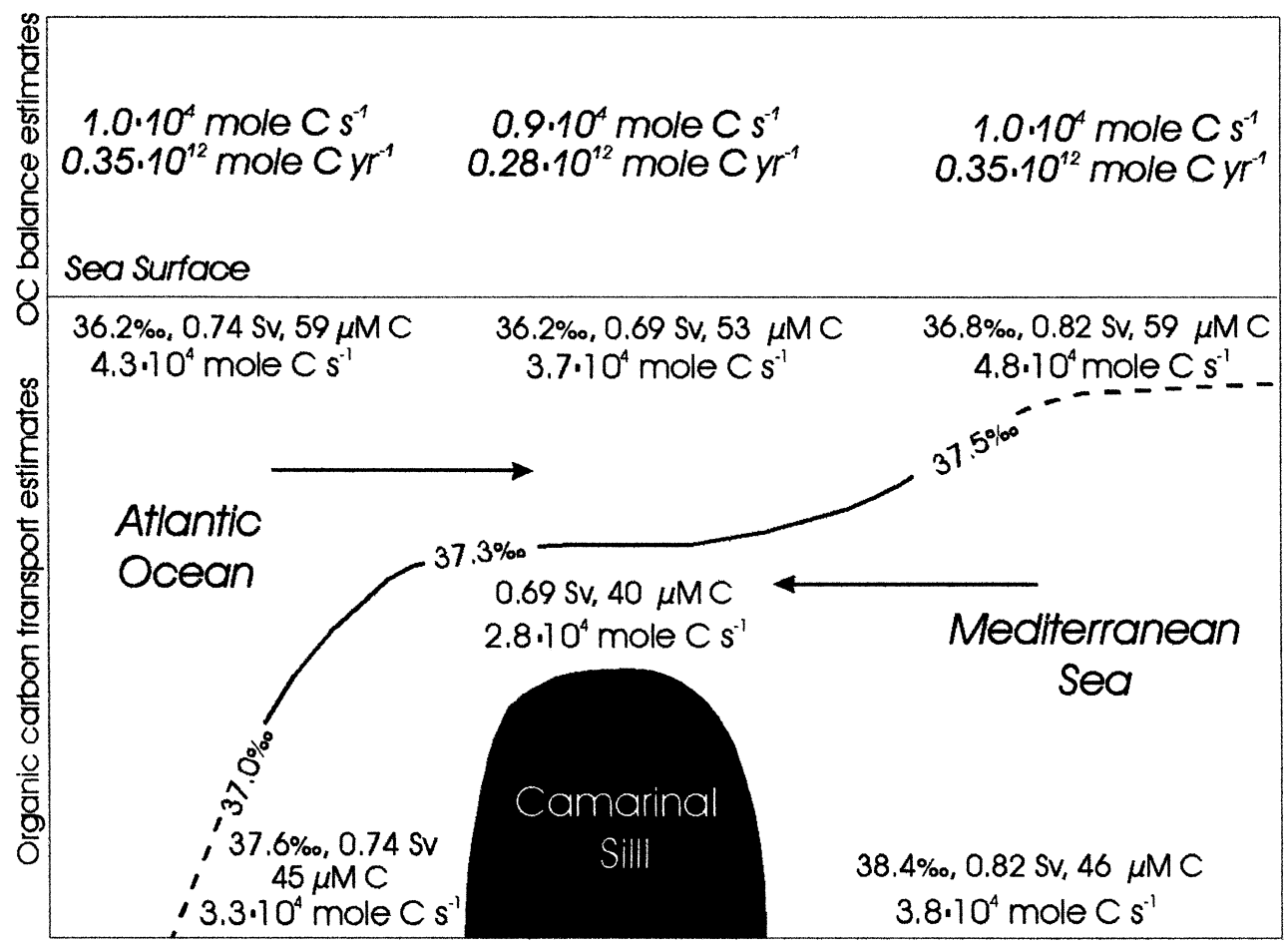

Fig. 9. Two layers model of water masses exchange through the Strait of Gibraltar with average values of salinity, mass transports in the Atlantic inflow and Mediterranean outflow based on the data of the Gibraltar experiment (Bryden et al., 1994; Bray et al., 1995) and CANIGO observations. These values of mass transport and average TOC concentration in each water layer were used for calculations of TOC transports (lower panel) and balances (upper panel) along the Strait.

$0.28 \times 10^{12}$ to $0.35 \times 10^{12}$ mol C year ${ }^{-1}$, respectively). The TOC balance is a function of water transport and TOC concentration. For example, from both entrances of the Strait, similar average TOC concentrations in the Atlantic inflow as well as in the Mediterranean outflow (59 and 45-46 $\mu \mathrm{M} \mathrm{C}$, respectively) were observed, but different estimates of water transport were used (Fig. 9). By contrast, at Tarifa Narrows, the water transports in Atlantic inflow and Mediterranean outflow were similar (0.7 Sv) but concentrations of TOC were different (53 and $40 \mu \mathrm{M} \mathrm{C}$, respectively) and, consequently, different balance estimates were obtained.

Several authors have evaluated the budget of dissolved organic nitrogen and phosphorus through the Strait (Béthoux and Copin-Montégut, 1986; Coste et al., 1988); they have found that inflow of these organic compounds exceeded their outflow from the Mediterranean Sea. Our data together with results quoted above indicate that inflow of organic material to the Mediterranean Sea through the Strait of Gibraltar is considerably higher than outflow. We think that this feature is mostly due to the high biological productivity of the Gulf of Cádiz, where we observed high DOC concentrations $(89 \mu \mathrm{M} \mathrm{C})$ even in the winter season (Dafner et al., 1999).

An indirect estimate of the organic carbon budget through the Strait of Gibraltar was also recently evaluated by Copin-Montégut (1993). She presented a value as high as $1.25 \times 10^{12}$ mol C year $^{-1}$, that is, threefold to fourfold higher than our estimates. Polat and Tugrul (1996) have obtained a value of $1.79 \times$ $10^{4}$ tons $\mathrm{C}$ year $^{-1}$ (or $0.15 \times 10^{10} \mathrm{~mol} \mathrm{C} \mathrm{year}^{-1}$ ) for organic carbon export from the Marmara to the Aegean Sea and about of $0.41 \times 10^{4}$ tons $\mathrm{C}$ year ${ }^{-1}$ $\left(0.34 \times 10^{9}\right.$ mol C year $\left.^{-1}\right)$ for the outflow from the Aegean Sea to the Marmara Sea. River TOC inputs have been estimated to $20-83 \times 10^{10}$ mol C year $^{1}$ (Sempéré et al., 1999 and references therein). These data indicate that TOC inflow through the Strait of Gibraltar is two orders of magnitude higher than through the Turkish Straits and than Mediterranean River inputs. The Mediterranean outflow through the Strait of Gibraltar is also higher by three orders of 
magnitude than through the Turkish Straits. It is likely that these budgets are reflections of the productivity of the seas adjoining to the straits - the mesotrophic Alboran Sea to the east from the Strait of Gibraltar, and the oligotrophic Aegean Sea to the west from the Turkish Straits.

\section{Conclusions}

TOC concentrations found in the surface layer of the Strait of Gibraltar area are in agreement with those previously reported for the Atlantic Ocean and Mediterranean Sea (ca. 60-70 $\mu$ M C). Our estimates of the TOC pool in the deep waters of the Western Alboran Sea (38-52 $\mu \mathrm{M} \mathrm{C}$ ) differ slightly from those published recently for the Mediterranean Sea, suggesting on a participation of bacteria on turnover of the organic material inside the LIW on its way to the Strait of Gibraltar. The correlation between TOC and salinity was found in the Western Alboran Sea $(r=0.69, n=120)$ where the water column was characterised by a thicker layer of SAW and by a thinner layer of the Mediterranean waters. In the Gulf of Cádiz, the water column was under the influence of the short-term variability caused by tides, SAW was thicker, Mediterranean waters was thinner and an additional water body was found (modified NACW). Accordingly, this relationship was characterised by a large bias. The correlations between TOC and AOU, and TOC and fluorescence over the entire water column are observed. These correlations are due to the decrease of both properties with depth rather than biological processes.

For calculation of the TOC transport, the two-layer model of water mass exchange through that Strait was used. Estimates of the TOC budget ranged from $0.28 \times 10^{12}$ to $0.35 \times 10^{12}$ mol C year $^{-1}$. Our computations of the TOC budget suggest that TOC inflow is two-and outflow is three orders of magnitude higher through the Strait of Gibraltar then via the Turkish Straits. The amount of TOC transporting throughout the Strait of Gibraltar show that the TOC flux by Atlantic inflow and the Mediterranean outflow cannot be ignored in the modelling of carbon cycle in the Mediterranean Sea and the eastern North Atlantic Ocean.

\section{Acknowledgements}

We thank the crew of the RRV Discovery for help and support. We acknowledge R. Boscolo and E. Oikonomou for allowing us to use their unpublished data for oxygen. Our special thanks go to J.H. Sharp, who kindly provided the Deep Atlantic and low carbon water reference standards. We thank P.J. Wangersky, D.A. Hansell and G. Cauwet for critical reading and constructive comments on the development of the manuscript. This research was funded by the European Commission, MAST III Programme (Contract MAS3-CT96-0060). Financial support for E.V. Dafner came from Ministere Affaires Etrangères Francais and Conseil Général des Bouches du Rhône, France. Some of the ideas presented here reflect discussions held at several CANIGO Workshops.

\section{References}

Andrie, C., Merlivat, L., 1988. Tritium in the western Mediterranean Sea during 1981 Phycemed cruise. Deep-Sea Res. 35, 247-267.

Antoine, D., Morel, A., André, J.M., 1995. Algal pigment distribution and primary production in the eastern Mediterranean as derived from coastal zone colour scanner observations. J. Geophys. Res. 100 (C8), 16193-16209.

Armi, L., Farmer, D.M., 1989. The exchange flow in the Strait of Gibraltar. In: Almazan, J.L., Bryden, H., Kinder, T., Parilla, G. (Eds.), Seminario Sobre la Oceanografia Fisica del Estrechode Gibraltar, Madrid, 24-28 Octobre 1988, SECEG, Madrid. pp. 366-374.

Bauer, J.E., Williams, P.M., Druffel, E.R.M., Suzuki, Y., 1990. Deep profiles of dissolved organic carbon in the Sargasso Sea. Eos Trans., AGU 71, 154.

Béthoux, P., Copin-Montégut, G., 1986. Biological fixation of atmospheric nitrogen in the Mediterranean Sea. Limnol. Oceanogr. 31 (6), 1353-1358.

Béthoux, J.P., Gentili, B., Raunet, J., Taillez, D., 1990. Warming trend in the Western Mediterranean deep water. Nature (London) 347, 660-662.

Bray, N.A., Ochoa, J., Kinder, T.N., 1995. The role of the interface in exchange through the Strait of Gibraltar. J. Geophys. Res. 100 (C6), 10755-10776.

Bryden, H.L., Kinder, T.N., 1988. Gibraltar experiment: a plan for dynamic and kinematic investigations of strait mixing, exchange and turbulence. Oceanol. Acta SP, 29-40.

Bryden, H.L., Kinder, T.H., 1991. Recent progress in strait dynamics. Rev. Geophys. 617-631, April 1991, Suppl.

Bryden, H.L., Stommel, H.M., 1982. Origins of the Mediterranean outflow. J. Mar. Res. 40, 55-71. 
Bryden, H.L., Brady, E.C., Pillsbury, R.D., 1989. Flow through the Strait of Gibraltar. In: Almazan, J.L., Bryden, H., Kinder, T., Parilla, G. (Eds.), Seminario Sobre la Oceanografia Fisica del Estrechode Gibraltar, Madrid, 24-28 Octobre 1988, SECEG, Madrid, pp. 166-194.

Bryden, H.L., Candela, J., Kinder, T.H., 1994. Exchange through the Strait of Gibraltar. Prog. Oceanogr. 33, 201-248.

Cano, N., 1978. Resultados de la campaña 'Alborán-76'. Bol. Inst. Esp. Oceanogr. 247, 3-50.

Cauwet, G., 1994. HTCO method for dissolved organic carbon analysis in seawater: influence of catalyst on blank estimation. Mar. Chem. 47, 55-64.

Christensen, J.P., Packard, T.T., Dortch, F.Q., Minas, H.J., Gascard, J.C., Richez, C., Garfield, P.C., 1990. Carbon oxidation in the deep Mediterranean Sea: evidence for dissolved organic carbon source. Global Biogeochem. Cycles 3 (4), 315-335.

Copin-Montégut, C., 1993. Alkalinity and carbon budgets in the Mediterranean Sea. Global Biogeochem. Cycles 7 (4), 915925.

Coste, B., Le Corre, P., Minas, H.J., 1988. Re-evalution of the nutrient exchange in the Strait of Gibraltar. Deep-Sea Res. 35 (5), 767-775.

Dafner, E.V., Sempéré, R., González, N., Gomez, F., Goutx, M., 1999. Cross-slope variations of dissolved organic carbon in the Gulf of Cádiz in relation to water dynamics (February 1998). Mar. Ecol.: Prog. Ser. 189, 301-306.

De Baar, H.J.W., Brussaard, C., Hegeman, J., Schijt, J., Stoll, M.N.C., 1993. Sea-trails of three different methods for measuring non-volatile dissolved organic carbon in seawater during the J-GOFS North Atlantic pilot study. Mar. Chem. 41, $145-152$

Doval, M.O., Pérez, F.F., Berdalet, E., 1999. Dissolved and particulate organic carbon in the North-Western Mediterranean Sea. Deep-Sea Res. I 46 (3), 511-527.

Doval, M.D., Hansell, D.A., 2000. Organic carbon and apparent oxygen utilization in the Western South Pacific and the Central Indian Ocean. Mar. Chem. 68 (3), 249-264.

Druffel, E.R.M., Williams, P.M., Suzuki, Y., 1989. Concentrations and radiocarbon signature of dissolved organic matter in the Pacific Ocean. Geophys. Res. Lett. 16, 991-994.

Francour, P., Boudouresque, C.F., Harmelin, J.G., HarmelinVivien, M.L., Quignard, J.P., 1994. Are the Mediterranean waters becoming warmer? Information from biological indicators. Mar. Pollut. Bull. 28 (9), 523-526.

Gascard, J.C., Richez, C., 1985. Water masses and circulation in the western Alboran Sea and in the Strait of Gibraltar. Prog. Oceanogr. 15, 157-216.

Gil, J., Gomiz, D., 1994. Circulación geostrófica, dinámica de mesoescala y fertilización de aguas someras en el sector notre del Mar de Alborán. Bol. Inst. Esp. Oceanogr. 10, 95-117.

Greze, V.N., Kovalev, A.V., Baldina, E.P., Bileva, O.K., Shmeleva, A.A., 1985. Zooplankton transfer through the Gibraltar Strait and peculiarities of its taxonomic composition and distribution in adjacent areas. Invest. Pesq. 49 (1), 3-13.

Gründlich, M.L., 1981. On the observation of a solitary event in the Mediterranean outflow west of Gibraltar. "Meteor" Forschungsergeb., Reihe A/B 23, 15-46.
Guimerans, V., Cañavate, R., Palma, R., 1988. Contribution to the knowledge of the Gibraltar sill. In: Almazan, J.L., Bryden, H., Kinder, T., Parilla, G. (Eds.), Seminario Sobre la Oceanografia Fisica del Estrechode Gibraltar, Madrid, 24-28 Octobre 1988, SECEG, Madrid, p. 83.

Hansell, D.A., Carlson, C.A., 1998. Deep ocean gradient in concentrations of dissolved organic carbon. Nature 395, 263 266.

Hansell, D.A., Williams, P.M., Ward, B.B., 1993. Measurements of DOC and DON in the Southern California bight using oxidation by high temperature combustion. Deep-Sea Res., Part I 40, 219-234.

Johnson, R.G., 1997. Climate control requires a dam at the Strait of Gibraltar. Eos Trans., AGU 78 (277), 280-281.

Kepkay, P.E., Wells, M.L., 1992. Dissolved organic carbon in North Atlantic surface waters. Mar. Ecol.: Prog. Ser. 80, 275-283.

Kumar, M.D., Rajendran, A., Somasundar, K., Haake, B., Jenisch, A., Shuo, Z., Ittekkot, V., Desai, B.N., 1990. Dynamics of dissolved organic carbon in the north-western Indian Ocean. Mar. Chem. 31, 299-316.

Lacombe, H., Richez, C., 1982. The regime of the Strait of Gibraltar. In: Nihoul, C.J. (Ed.), Hydrodynamics of Semienclosed Seas. Elsevier, Amsterdam, pp. 13-73.

Lacombe, H., Gascard, J.C., Gonella, J., Bethoux, J.P., 1981. Response of the Mediterranean to the water and energy fluxes across its surface, on seasonal and interannual scales. Oceanol. Acta 4, 247-255.

La Violette, P.E., Lacombe, H., 1988. Tidal-induced pulses in the flow through the Strait of Gibraltar. Oceanol. Acta, N SP, $13-27$.

Martin, J.H.S., Fitzwater, S.E., 1992. Dissolved organic carbon in the Atlantic, Southern and Pacific Oceans. Nature (London) 356, 699-700.

McGill, D.A., 1961. A preliminary study of the oxygen and phosphate distribution in the Mediterranean Sea. Deep-Sea Res. 8, 259-269.

Measures, C.I., Edmond, J.M., 1988. Aluminum as a tracer of the deep outflow from the Mediterranean Sea. J. Geophys. Res. 93 (C1), 591-595.

Medoc Group, 1970. Observation of formation of Deep Water in the Mediterranean Sea. Nature (London) 227, 1037-1040.

Minas, H.J., Minas, M., 1993a. Influence du détroit de Gibraltar sur la biogéochimie de la Méditerranée et du proche Atlantique. Ann. Inst. Oceanogr. (Paris) 69 (1), 203-214.

Minas, H.J., Minas, M., 1993b. Primary productivity in relation to nutrient cycling and water circulation in the Mediterranean Sea. Proc. 4th Nat. Symp. Oceanogr. Fish., Rhodes Isl., (Greece), 26-29 April, pp. 123-143.

Minas, H.J., Coste, B., Le Corre, P., Minas, M., Raimbault, P., 1991. Biological and geochemical signatures associated with the water circulation through the Strait of Gibraltar and in the Western Alboran Sea. J. Geophys. Res. 96 (C5), 8755-8771.

Ogawa, H., Ogura, N., 1992. Comparison of two methods for measuring dissolved organic carbon in sea water. Nature (London) 356, 696-698.

Packard, T.T., Minas, H.J., Coste, B., Martinez, R., Bowin, M.C., 
Gostan, J., Garfield, P., Christensen, J., Dortch, D., Minas, M., Copin-Montégut, G., Copin-Montégut, C., 1988. Formation of the Alboran oxygen minimum zone. Deep-Sea Res. 35 (7), 1111-1118.

Parrilla, G., Kinder, T., 1987. The physical oceanography of the Alboran Sea. Bol. Inst. Esp. Oceanogr. 4 (1), 133-165.

Peltzer, E.T., Hayward, N.A., 1996. Spatial and temporal variability of total organic carbon along $140^{\circ} \mathrm{W}$ in the equatorial Pacific Ocean in 1992. Deep-Sea Res., Part II 43 (4-6), $1155-1180$.

Polat, Ç., Tugrul, S., 1996. Chemical exchange between the Mediterranean and the Black Sea via the Turkish straits. Bull. Inst. Oceanogr. 17, 167-186, Monaco, CIESM Science Series 2, SP.

Price, J.F., Baringer, M.O., Lueck, R.G., Johnson, G.C., Ambar, I., Parrilla, G., Cantos, A., Kennely, M.A., Sanford, T.B., 1993. Mediterranean outflow mixing and dynamics. Science 259, 1277-1282.

Rahmstorf, S., 1998. Influence of Mediterranean outflow on climate. Eos Trans., AGU 79 (24), 281-282.

Redfield, A.C., Ketchum, B.H., Richards, F.A., 1963. The influence of organisms on the composition of seawater. In: Hill, M.N. (Ed.), The Sea vol. 2. Interscience, New York, pp. 26-77.

Roether, W., Weiss, W., 1975. On the formation of the outflow through the Strait of Gibraltar. Geophys. Res. Lett. 2, 301-304.

Rohling, E.J., Bryden, H.L., 1992. Man-induced salinity and temperature increases in Western Mediterranean Deep Water. J. Geophys. Res. 97 (C7), 11191-11198.

Rodríguez, J., Blanco, J.M., Jimènez-Gómez, F., Echevarría, F., Gil, J., Rodrígues, V., Ruiz, J., Bautista, B., Guerrero, F., 1998. Patterns in the size structure of the phytoplankton community in the deep fluorescence maximum of the Alboran Sea (southwestrn Mediterranean). Deep-Sea Res., Part I 45, $1577-1593$.

Sempéré, R., Charrière, B., Van Wambeke, F., Cauwet, G., 1999. Carbon inputs of the Rhone River to the Mediterranean Sea: biogeochemical implications. Global Biogeochem. Cycles, in press.

Sharp, J.H., 1994. The broad community DOC methods comparison. Eos Trans., AGU 75, 106, Suppl.

Sharp, J.H., Benner, R., Bennet, L., Carlson, C.A., Fitzwater, S.E., Peltzer, E.T., Tupas, L.M., 1995. Analyses of dissolved organic carbon in seawater: the JGOFS EqPac methods comparison. Mar. Chem. 48, 91-108.

Skoog, A., Thomas, D., Lara, R., Richter, K.U., 1997. Methodical investigations on DOC determinations by the HTCO method. Mar. Chem. 56, 39-44.
Stanton, B.R., 1983. Low frequency variability in the Mediterranean Outflow west of Gibraltar. Deep-Sea Res. 30 (7A), 743-761.

Stommel, N., 1972. Deep winter-time convection in the western Mediterranean Sea. In: Gordon, A.L. (Ed.), Stud. Phys. Oceanogr., vol. 2, Gordon \& Breach, New York, p. 232.

Stratford, K., Williams, R.G., 1997. A tracer study of the formation, dispersal, and renewal of Levantine Intermediate Water. J. Geophys. Res. 102 (C6), 12,539.

Sugimura, Y., Suzuki, Y., 1988. A high temperature catalytic oxidation method of non-volatile dissolved organic carbon in seawater by direct injection of liquid samples. Mar. Chem. 24, $105-131$

Tanoue, E., 1992. Vertical distribution of dissolved organic carbon in the North Pacific as determined by the high-temperature catalytic oxidation method. Earth Planet. Sci. Lett. 111, 201-216.

Toggweiler, J.R., 1989. Is the downward dissolved organic matter (DOM) flux important in carbon transport? In: Berger, W.F., Smetachek, V.S., Wefer, G. (Eds.), Productivity in the Ocean: Past and Present. Wiley, New York, pp. 65-83.

Toggweiler, J.R., 1992. Catalytic conversation. Nature (London) 356, 665-666.

Thomas, C., Cauwet, G., Minster, J.F., 1995. Dissolved organic carbon in the equatorial Atlantic Ocean. Mar. Chem. 49, $155-169$.

Van Geen, A., Boyle, E., 1989. Atlantic water masses in the Strait of Gibraltar: inversion of trace metal data. In: Almazan, L., Bryden, H., Kinder, T., Parilla, G. (Eds.), Seminario Sobre la Oceanografia Fisica del Estrechode Gibraltar, Madrid, 24-28 Octobre 1988, SECEG, Madrid, pp. 68-81.

Van Geen, A., Rosener, P., Boyle, E., 1988. Entrainment of trace-metal-enriched Atlantic-shelf water in the inflow to the Mediterranean Sea. Nature (London) 331, 423-426.

Van Geen, E., Boyle, A., Moore, W.S., 1991. Trace metals enrichments in waters of Gulf of Cádiz, Spain. Geochim. Cosmochim. Acta 55, 2173-2191.

Walsh, J.J., Carder, K.L., Müller-Karger, F.E., 1992. Meridional fluxes of dissolved organic matter in the North Atlantic Ocean. J. Geophys. Res. 97 (C10), 15625-15637.

Wesson, J.C., Gregg, M.C., 1994. Mixing at Camarinal Sill in the Strait of Gibraltar. J. Geophys. Res. 99 (C5), 9847-9878.

Wiebinga, C.J., De Baar, H.J.W., 1998. Determination of the distribution of dissolved organic carbon in the Indian sector of the Southern Ocean. Mar. Chem. 61, 185-201. 